\title{
EFEITO DO BISEL NA INFILTRAÇÃO MARGINAL EM RESTAURAÇÕES CLASSE IV DE RESINA COMPOSTA
}

\section{SÉRGIO KATSUO MIZUNO}

Dissertação apresentada à Faculdade de Odontologia de Bauru da Universidade de São Paulo, como parte dos requisistos para obtenção do título de Mestre em Odontologia, na área de Dentística.

(Edição Revisada)

Bauru

2003 


\section{EFEITO DO BISEL NA INFILTRAÇÃO MARGINAL EM RESTAURAÇÕES CLASSE IV DE RESINA COMPOSTA}

\section{SÉRGIO KATSUO MIZUNO}

Dissertação apresentada à Faculdade de Odontologia de Bauru da Universidade de São Paulo, como parte dos requisistos para obtenção do título de Mestre em Odontologia, na área de Dentística.

Orientador: Prof. Dr. José Mondelli

Bauru

2003 


\begin{tabular}{|l} 
Mizuno, Sérgio Katsuo \\
Efeito do bisel na infiltração marginal em restaurações \\
Classe IV de resina composta / Sérgio Katsuo Mizuno, - \\
Bauru, 2003. \\
$76 p$. :il.; $31 \mathrm{~cm}$. \\
Dissertação (Mestrado) - Faculdade de Odontologia de \\
Bauru. USP. \\
Orientador: Prof. Dr. José Mondelli
\end{tabular}

Autorizo, exclusivamente para fins acadêmicos e científicos, a reprodução total ou parcial desta dissertação, por processos fotocopiadores e outros meios eletrônicos.

Assinatura do autor:

Data: 03.02 .2003 


\section{Sérgio Katsuo Mizuno}

Nascimento: 27 de março de 1961, em Londrina - PR

Filiação: Kiyokatsu Mizuno

Tereza Fumie Mizuno

1980 - 1984 Curso de Graduação em Odontologia

Universidade Estadual de Londrina (UEL), Londrina - PR

1988 - 1989 Especialização em Prótese Dental

Associação Odontológica Norte do Paraná, Londrina - PR

1991 - 1998 Professor Assistente, Disciplina Dentística

Universidade Norte do Paraná, Londrina - PR

1993 Aperfeiçoamento em Prótese Parcial Removível Universidade Cidade de São Paulo (UNICID), São Paulo - SP

1994 - 2003 Professor Assistente, Disciplina Prótese Parcial Removível Universidade Norte do Paraná, Londrina - PR

Associações $\quad$ ABO - Associação Brasileira de Odontologia, Secção Londrina - PR

GBPD - Grupo Brasileiro de Professores de Dentística 


\section{DEDICATÓRIA}

Ao meu pai Kiyokatsu (in memorian) e à minha mãe Tereza, que nunca pouparam sacrifícios para dar educação aos filhos.

Que não mediram esforços para dar o tão sonhado diploma, a melhor herança que um pai pode deixar para os filhos. A vocês, que sempre incentivaram nos estudos, porque não tiveram a oportunidade que tive, minha eterna gratidão.

\section{Ao meu avô Hisatomi e à minha avó Shiguemi,} duas pessoas que foram muito importantes na minha vida, mesmo não estando mais entre nós, foram também responsáveis diretos por isso.

À minha esposa Márcia, pelo seu amor, compreensão, sacrifício e apoio. A você, que teve de suprir a minha ausência em muitos momentos em família, meu eterno amor.

\section{Aos meus queridos filhos}

Felipe, Rafael e Letícia: pelo amor e compreensão de vocês, que muitas vezes não tiveram a companhia do pai atarefado e envolvido com o trabalho do mestrado.

A vocês, minhas crianças, o meu amor infinito.

\section{Com muito amor, um eterno obrigado!}




\section{AGRADECIMENTO ESPECIAL}

Ao Prof. Dr. José Mondelli, meu orientador, o sincero agradecimento.

Agradeço por tê-lo como orientador, um ser humano sensível e admirável. Um profissional e pesquisador competente e dedicado, por isso tão respeitado por todos aqueles que o conhecem.

Agradeço a sua amizade, o esforço e o apoio dispensados para que eu pudesse atingir mais este objetivo.

Com admiração, muito obrigado! 


\section{MEU SINCERO AGRADECIMENTO}

Ao Prof. Dr. Newton Expedito de Moraes, coordenador operacional do curso de Mestrado Interinstitucional em Odontologia UELFOB/USP. Minha estima e gratidão por ter incentivado a realização desse curso a muitos profissionais e professores que até então não tinham tido condições ou oportunidades de conquistar novos conhecimentos e titulação. Meu reconhecimento pelo sacrifício e pelas dificuldades encontradas para esta conquista, em benefício do próximo.

À Prof. ${ }^{a}$ Dr. $^{a}$ Maria Fidela de Lima Navarro, diretora da FOB/USP e coordenadora acadêmica, grande colaboradora e uma das responsáveis pela aprovação do curso de Mestrado Interinstitucional. Profissional dedicada, foi apoio e incentivo mesmo a quilômetros de distância, não deixando ninguém desamparado. Meu reconhecimento pela sua competência, com profunda admiração.

Sinceramente, de coração 


\section{Agradeço ainda:}

À Universidade Norte do Paraná - UNOPAR / Londrina.

À Universidade Estadual de Londrina - UEL.

À Faculdade de Odontologia de Bauru - USP.

Aos companheiros de trabalho, professores da UNOPAR Toshihiko Tan, Maurício Sella e Alexandre Belluomini, os quais não mediram esforços para suprir minha ausência.

Ao professor José Roberto Lauris, pelo apoio, dedicação e eficiência na elaboração e interpretação da análise estatística.

Aos professores do Departamento de Dentística, Endodontia e Materiais Dentários da Faculdade de Odontologia de Bauru, Doutores Aquira Ishikiriama, Carlos Eduardo Francischone, Eduardo Batista Franco, José Mondelli, José Carlos Pereira, Maria Fidela de Lima Navarro, Maria Teresa Atta, Mário Honorato da Silva e Souza Júnior, Rafael Lia Mondelli e Ricardo Marins de Carvalho.

Ao ex-professor e colega de disciplina, Toshihiko Tan, minha gratidão pelo apoio e incentivo. Um exemplo como pessoa e profissional dedicado à Odontologia. Mesmo sabendo das minhas limitações, acreditou no meu objetivo, fazendo com que minha vida tomasse um novo rumo.

Ao presidente da Comissão de Pós-graduação da FOB/USP, Prof. Dr. José Carlos Pereira.

À Elisabeth Cariani, assessora da diretoria da Faculdade de Odontologia de Bauru.

À Maria Celeste Morita, coordenadora do Curso de Odontologia da UNOPAR, meu reconhecimento pela sua competência. 
Aos colegas do curso de Mestrado Celia Fornaziero, Cintia Murad, Cyntia Rigolon, Denilson Cavina, Jefferson Morioka, Maristera Azarak, Vânia Queiroz, Virgínia Bosquiroli, e em especial, Bruno Barbosa Campos, pela amizade, colaboração e grande dedicação dispensadas.

Ao Ricardo A. Campos, secretário do curso de Mestrado, sempre disposto e prestativo.

À CAPES, pelo apoio financeiro.

Aos funcionários do Serviço de Biblioteca da Faculdade de Odontologia de Bauru, em especial a Rita Cássia Paglione e Valéria Cristina T. Ferraz.

Aos funcionários da Biblioteca da UNOPAR, em especial Eliani Schlieper e Sonia Pósnik.

Às secretárias do Departamento de Dentística, Endodontia e Materiais Dentários da Faculdade de Odontologia de Bauru, Eloísa, Rita, Ângela e Karen, pelos serviços prestados.

Ao polivalente Nelson, pessoa importante para a realização da parte prática deste trabalho.

Aos meus irmãos Mauro e Lauro, amigos de sempre, desde as brincadeiras de infância até os projetos pessoais e profissionais.

\section{A todos, meu reconhecimento.}




\section{SUMÁRIO}

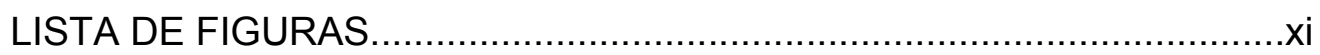

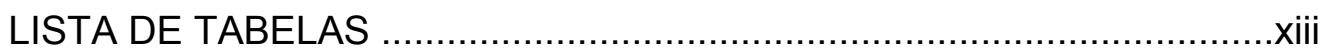

LISTA DE ABREVIATURAS ..................................................

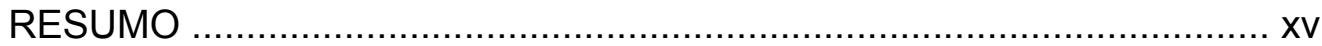

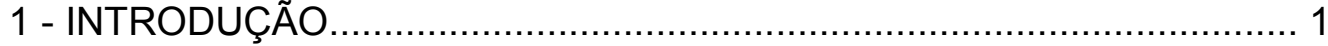

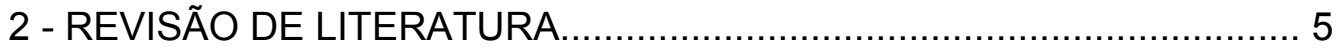

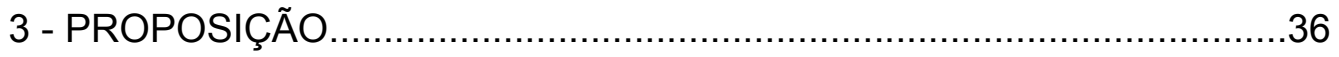

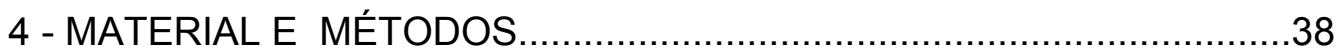

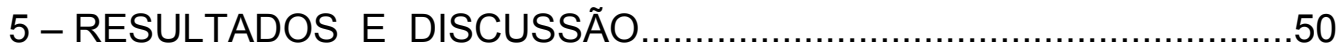

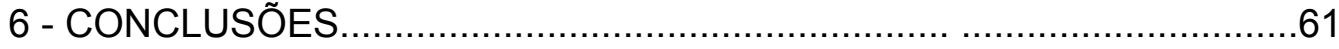

REFERÊNCIAS BIBLIOGRÁFICAS ...............................................63

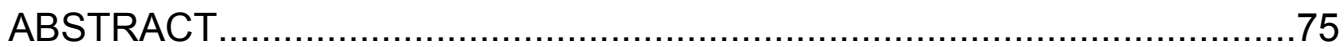




\section{LISTA DE FIGURAS}

Figura 1 - Cavidades Classe IV apresentadas por BLACK com bisel para materiais metálicos de uso direto (ouro em folha)

Figura 2 - Desenho esquemático das características do bisel apresentados por (HOWARD)

Figura 3 - Desenhos esquemáticos dos princípios de resistência e retenção para restaurações Classe IV, apresentados por CORREA.

Figura 4 - Preparo com sinuosidades para fraturas de ângulos de HINDING

Figura 5 - Cavidade Classe IV com ombro escalonado. .10

Figura 6 - Esquema das cavidades empregadas por ERIKESEN, BUONOCORE 11

Figura 7 - Desenho esquemático da variação do bisel nas cavidades apresentadas por OILO;JORGENSEN

Figura 8 - Variações de tratamento do ângulo cavossuperficial, testados por ELIASON; HILL

Figura 9 - Desenho esquemático da extensão e do comprimento do bisel, BAGHERI; DENEHY.

Figura 10 - Formas cavitárias ensaiadas por PORTE et al. 16

Figura 11 - Esquema de cavidade preparada, DARVENIZA. 18

Figura 12 - Esquema para cavidades extensas cavidades de Classe IV, DARVENIZA

Figura 13 - Cavidades Classe IV para utilização da técnica do condicionamento ácido como meio de retenção, CHAN; COOLEY 
Figura 14 - Preparo do bisel e restauração de Classe IV, MONDELLI, J. et al., em 1984; com resina acrílica ativada quimicamente, no incisivo lateral superior direito

Figura 15 - Vista vestibular do preparo padronizado por ATTIN et al. 32

Figura 16 - Cavidades Classe IV sem bisel. .41

Figura 17 - Cavidades Classe IV com bisel

Figura 18 - Conjunto restaurador adesivo. .43

Figura 19 - Dente bovino sem preparo, com preparo Classe IV e restaurado. 44

Figura 20 - Impermeabilização do dente com esmalte de unha cobrindo o dente, com exceção de $1 \mathrm{~mm}$ ao redor da restauração. 45

Figura 21 - Máquina de termociclagem, ÉTICA onde o conjunto dente restauração foram submetidos ao choque térmico. .45

Figura 22 - Extremidade direita do tubo de PVC vedada com resina, que também fixava o dente por sua raiz. Aextremidade esquerda foi seccionada para permitir o carregamento axial, através de uma ponta torneada de forma esférica com $2 \mathrm{~mm}$ de diâmetro 46

Figura 23 - Dente imerso na solução corante para receber a carga

Figura 24 - Máquina universal de ensaio EMIC, pertencente ao Laboratório de Dentística da FOB-USP.

Figura 25 - Dente imerso em fucsina básica, no interior do tubo de PVC. 48

Figura 26 - Corpo-de-prova em posição, por meio do posicionador de ângulo e ponta cônica incidindo na face palatina da restauração, a fim de aplicar o carregamento axial de compressão (ciclagem mecânica) .48

Figura 27 - Amostra das secções obtidas .58 


\section{LISTA DE TABELAS}

Tabela 1- Apresentação dos grupos experimentais em relação a número de dentes e a presença ou ausência do bisel.

Tabela 2- Valores médios, desvio-padrão e mediana de penetração linear do corante, medidos em milímetros .57

Tabela 3- Valores de penetração do corante medidos em porcentagem.....58 


\section{Lista de abreviaturas e símbolos}

$\begin{array}{ll}\mathrm{min}= & \text { minuto } \\ \mathrm{mm}= & \text { milímetro } \\ \mathrm{mW}= & \text { miliwatt } \\ u \mathrm{~m}= & \text { micrômetro } \\ \mathrm{mW} / \mathrm{cm}^{2}= & \text { miliwatt por centímetro quadrado } \\ \mathrm{MPa}= & \text { Mega Pascal } \\ \mathrm{n} .=. & \text { número } \\ { }^{\circ} \mathrm{C}= & \text { Graus Celsius (Centígrados) } \\ \mathrm{cm}{ }^{2}= & \text { centímetro quadrado } \\ \mathrm{r} . \mathrm{p} . \mathrm{m} .= & \text { rotação por minuto } \\ \mathrm{kg}= & \text { quilograma } \\ \mathrm{kgf}= & \text { quilograma força } \\ \mathrm{X}= & \text { indica aumento em número de vezes } \\ \%= & \text { porcentagem } \\ <= & \text { menor que (para significância estatística) } \\ \mathrm{s}= & \text { segundos } \\ \pm= & \text { mais ou menos } \\ \mathrm{p}= & \text { probabilidade } \\ \mathrm{D} . \mathrm{P} .= & \text { desvio padrão } \\ & \end{array}$




\section{RESUMO}

O objetivo deste estudo foi avaliar o efeito do bisel na infiltração marginal em restaurações de resina composta em cavidades Classe IV sem e com bisel em todo ângulo cavossuperficial, submetidas à ciclagem térmica e mecânica.

Foram preparadas nas mesmas dimensões, variando na ausência ou presença de bisel, 30 cavidades de Classe IV em incisivos inferiores de bovinos. No grupo 1 não foi realizado bisel e no grupo 2 o bisel foi realizado com uma extensão aproximada de $1,0 \mathrm{~mm}$ ao redor de todo o ângulo cavossuperficial. As cavidades foram restauradas com o mesmo sistema adesivo e resina composta Single Bond Z-250 (3M). Após a restauração foi executado um acabamento inicial com lâminas de bisturi. Em seguida, os dentes foram armazenados em água deionizada a uma temperatura de $37^{\circ} \mathrm{C}$ durante sete dias. No sétimo dia foi realizada a complementação do acabamento e polimento.

Os grupos foram submetidos à ciclagem térmica com o tempo de imersão de 30 segundos em cada banho, a uma temperatura de $5{ }^{\circ} \mathrm{C}$ e $55^{\circ} \mathrm{C}$, por 500 ciclos. Logo após, os corpos-de-prova foram submetidos à ciclagem mecânica, utilizando a máquina universal de ensaio EMIC programada para executar um carregamento e descarregamento axial de compressão na face lingual de cada dente restaurado. Inicialmente, foi aplicada uma carga ascendente de 1 a $10 \mathrm{kgf}$ e descendente de 10 a $1 \mathrm{kgf}$ durante 30 segundos, perfazendo um total de 100 ciclos para cada corpode-prova. Durante este ensaio, a porção coronária dos dentes ficou submersa em fucsina básica a 0,5\%.

Após o término da ciclagem mecânica, os corpos-de-prova permaneceram por mais 24 horas mergulhados na mesma solução e, em seguida, foram lavados em água corrente por 12 horas. 
Cada dente foi seccionado em fatias transversais de aproximadamente $1,0 \mathrm{~mm}$, sendo selecionada a fatia que apresentou maior grau de infiltração. Para avaliação da infiltração marginal foi utilizado um programa de análise de imagens, Image Tools, no qual foi medida a extensão da penetração do corante em milímetros.

Os valores em milímetros da extensão de penetração do corante foram para os grupos 1 e 2; sendo 1,02 $\mathrm{mm}$ e 0,0 mm respectivamente. Aplicando o teste estatístico, verificou-se que houve diferença estatisticamente significante $(p<0,05)$ entre os valores de infiltração do grupo 1 (ausência de bisel) com os do grupo 2 (presença de bisel).

Concluiu-se que a presença do bisel diminui significativamente a infiltração marginal nas restaurações de Classe IV, restaurações estas confeccionadas com o sistema restaurador adesivo e resina composta. 
INTRODUÇÃO 


\section{INTRODUÇÃO}

Uma forte união aos tecidos do dente é uma propriedade muito desejável de um material restaurador. Seria uma possibilidade que eliminaria a necessidade de confecção de retenções adicionais nos preparos cavitários, evitando a remoção de estrutura dental sadia e permitindo uma melhor adesão das restaurações, sem infiltração marginal, e conseqüentemente com maior longevidade.

A evolução dos sistemas restauradores estéticos, tanto dos adesivos dentinários como dos materiais restauradores, teve início em 1955 com o pesquisador BUONOCORE ${ }^{10}$, quem promoveu o tratamento das superfícies de esmalte com soluções ácidas tornando mais eficiente o vedamento dessas restaurações junto à interface dente/restauração. A união com o esmalte seria de natureza micromecânica pela formação de porosidades nas superfícies do esmalte condicionadas pelo ácido.

Com isso, a forma geométrica das cavidades vem sendo modificada devido a melhor adesão aos substratos dentários: as formas de conveniência, resistência e retenção foram reconsideradas tecnicamente, exigindo menos desgaste de estrutura dentária sadia para o procedimento restaurador. A infiltração marginal que ocorre na interface do material restaurador e do dente caracteriza uma falha que conduz à sensibilidade pós-operatória, hipersensibilidade crônica, recidiva de cárie e problemas pulpares (GOING ${ }^{39}, 1972$; KIDD ${ }^{51}$, 1976; WALTON ${ }^{83}$, 1987). Portanto, a capacidade de se obter um completo vedamento marginal e duradouro é ainda o maior desafio da Odontologia adesiva.

Entretanto, a evolução dos sistemas adesivos para esmalte e dentina que promovem altos valores de resistência de união (CARDOSO; BRAGA; CARRILHO $^{16}, 1998$ ) tem permitido reduzir consideravelmente a contração dos materiais, melhorar a retenção e o vedamento marginal das restaurações (ZIVKOVIC ${ }^{85}$, 2000) e, conseqüentemente a sua longevidade. 
As cavidades anteriormente preparadas com 0 ângulo cavossuperficial em $90^{\circ}$ para cimento de silicato, resinas acrílicas e as primeiras resinas compostas, começaram a sofrer alterações por alguns autores $^{65,77}$. Estes passaram a indicar cavidades com bisel no ângulo cavossuperficial do esmalte, em $45^{\circ}$ com a superfície externa do dente; bisel longo em nível zero, em que a resina composta ultrapassa os limites cavitários; bisel chanfrado ou côncavo mais profundo com terminação mais nítida e com retenções adicionais no ângulo entre as paredes de fundo e circundantes.

A confecção do bisel foi sendo utilizada à medida que se observaram vantagens como a exposição dos prismas de esmalte transversalmente, aumento da área a ser condicionada e, com isso, o aumento da retenção do material restaurador ${ }^{4,21,25,38,49,50,62}$; beneficiando a estética ${ }^{13,21,25,76}$ ,prevenindo a ocorrência de fraturas marginais ${ }^{62}$, favorecendo o vedamento marginal da restauração e diminuindo a infiltração marginal ${ }^{13,25}$, $50,66,76$

Com o aperfeiçoamento das resinas compostas, dos adesivos dentinários e das técnicas restauradoras, alguns autores ${ }^{5,22,36}$ afirmam que não há necessidade de se realizar o bisel em cavidades preparadas para lesões incipientes em dentes anteriores, principalmente na parede lingual das cavidades de Classe III. No entanto, recomendam bisel em fraturas de ângulo com a configuração morfológica Classe IV. Justificam a não realização do bisel pelas seguintes razões:

- a estética pode ser solucionada sem bisel devido à variedade de cores de resina composta.

- não há necessidade de execução do bisel na face lingual, pois iria diminuir a espessura do material nessa região e expô-lo na função incisal $^{5,22,36}$.

Verificou-se que a maioria dos autores indicam para as cavidades de Classe IV, tanto para fraturas com configuração similar à Classe IV o bisel por vestibular assim como por lingual. Poucos, porém, indicam a utilização de retenções adicionais como pinos dentinários ${ }^{23}$, confecção de canaletas, 
orifícios ou cauda-de-andorinha ${ }^{23}$ para essas cavidades. Todavia, quase inexistem respostas, por meio de experimentos laboratoriais em acompanhamento clínico que comprovem cientificamente essas indicações, deixando interrogações quanto à efetividade ou não de retenções adicionais em restaurações de Classe IV, ou se somente o condicionamento ácido do esmalte/dentina é suficiente para proporcionar retenção adesiva que elimine completamente a necessidade do bisel ou de outras formas de retenção.

Apesar do avanço técnico-científico, a Odontologia necessita ainda de mais pesquisas que avaliem o comportamento e as propriedades dos materiais adesivos, sua interação com a configuração cavitária, de forma que possam constituir referência para utilização por parte dos clínicos. 
REVISÃO DE LITERATURA 


\section{REVISÃO DE LITERATURA}

A situação de perda do ângulo incisal de um dente anterior por cárie ou fratura com a necessidade de restauração foi classificada por BLACK ${ }^{7}$, em 1908, de cavidade Classe IV.

1- Sem perigo à polpa, com suficiente estrutura para a ancoragem na dentina entre a polpa e a borda incisal, a retenção mecânica adicional nesta região bem como nos outros ângulos da cavidade pode ser a escolha, por remover menos estrutura dental. A ancoragem com estas retenções está na dependência do tipo de estresse, o qual tende a deslocar a restauração da cavidade.

2- Não existindo parede suficiente para retenções adicionais no ângulo incisal da cavidade, um degrau sobre a borda incisal pode ser realizado.

3- Se nenhum dos planos acima puder ser realizado, a polpa poderá ser removida e a câmara coronária ser utilizada como ancoragem. Ainda comentou que a proximidade do ouro à polpa da cavidade Classe IV indicava o tratamento endodôntico lançando mão da porcelana como recurso estético ao invés do ouro em folha.

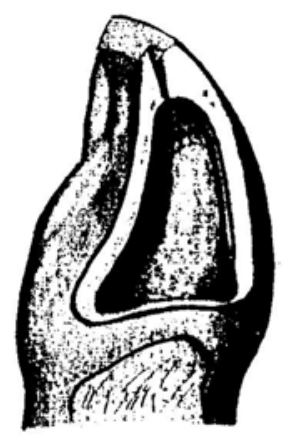

a

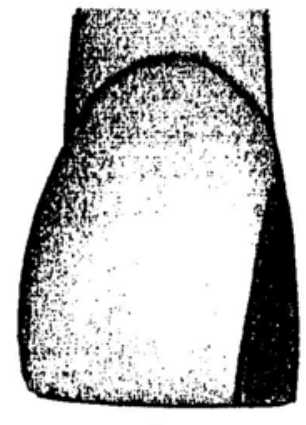

b

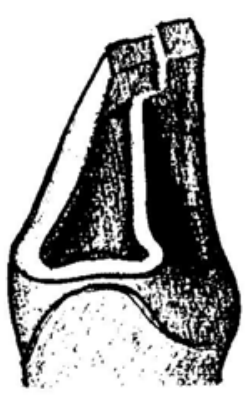

C

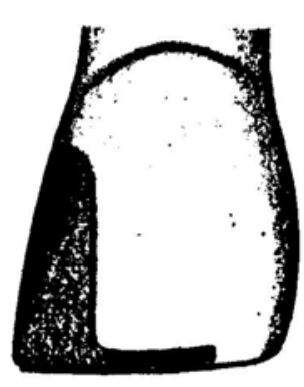

d

FIGURA 1 - Cavidades Classe IV apresentadas por BLACK ${ }^{7}$ com bisel para materiais metálicos de uso direto (ouro em folha)
a)- cavidade com retenção nos triedros
b)- restauração concluída
c)- cavidade com degrau incisal
d)- restauração concluída 
Segundo HOWARD ${ }^{48}$, em 1968, o bisel na preparação cavitária é a junção da parede formada pelo ângulo obtuso com a superfície do dente, tendo as características de um corte ou uma planificação realizada no plano de clivagem do esmalte, utilizada para restaurações de amálgama ou ouro. Os termos ligeiro bisel ("sligth bevel"), bisel curto ("short bevel"), bisel longo ("long bevel") e bisel completo ("full bevel") são terminologias usadas para descrever as características do bisel (Figura 2).

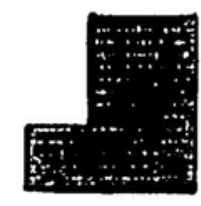

a

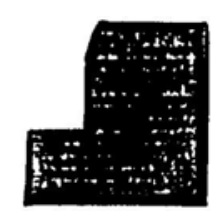

b

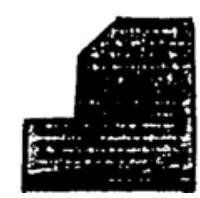

C

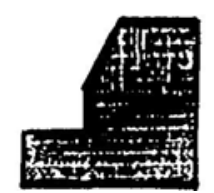

d

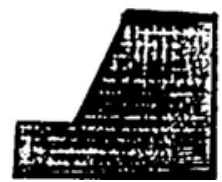

e

FIGURA 2 - Desenho esquemático das características do bisel apresentados por HOWARD ${ }^{48}$
a)- sem bisel (no bevel)
b)- ligeiro bisel (slight bevel)
c)- bisel curto (short bevel)
d)- bisel longo (long bevel)
e)- bisel completo (full bevel)

Em 1972, CORREA ${ }^{23}$ relatou no livro de PARULA que o operador deve considerar com relação às cavidades classe IV:

- extensão da cárie, morfologia do dente, oclusão e forças mastigatórias;

- exame radiográfico, para determinar a extensão e a forma da câmara pulpar;

- profundidade das retenções e reforços com pinos metálicos dependerão da espessura do tecido sadio visualizado pela radiografia.

Dependendo da extensão da cárie no preparo cavitário, o profissional deve observar:

1- Cárie debilitou o ângulo incisal: pode-se preparar uma cavidade próximo-incisal com retenção lingual em forma de cauda-deandorinha. 
2- Ângulo incisal e a borda incisal foram invadidos: deve-se preparar uma cavidade com reforço de fios metálicos.

Relatou, quanto às forças mastigatórias, que os movimentos mandibulares e as forças de oclusão são fatores que devem ser considerados, sendo forças ascendentes e descendentes que se originam durante a mastigação; bem como a pressão incisal das resultantes horizontais de desoclusão linguo-vestibular, que podem fraturar a parede vestibular ou deslocar a restauração. Por isso o preparo cavitário proximal, sem caixa ou reforço metálico, deve ser descartado.

Enfatizou que a inconveniência do preparo com cauda-de-andorinha em cavidades Classe IV é devido ao desgaste de tecido sadio na face palatina, além do risco de expor a polpa, preferindo o uso de reforço metálico.
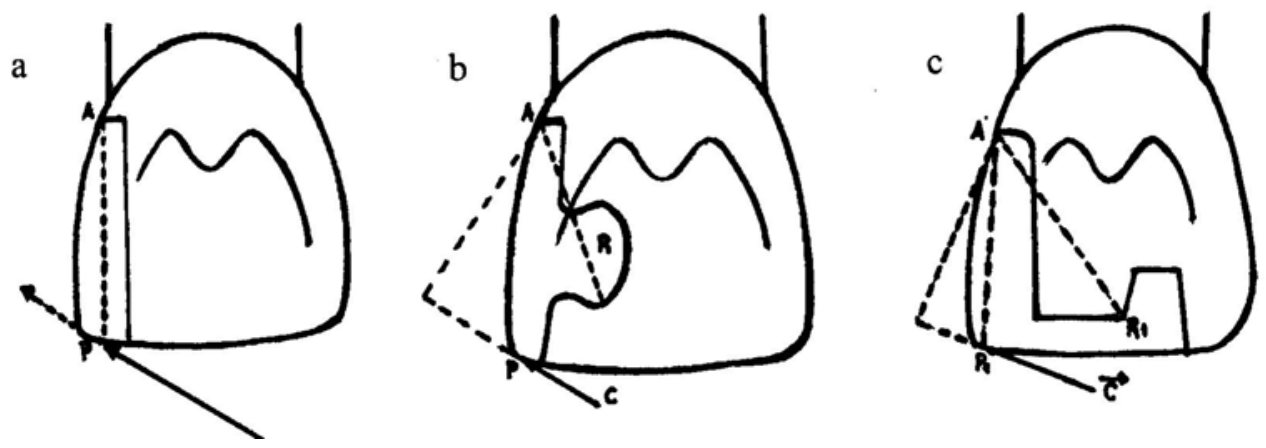

FIGURA 3 - Desenhos esquemáticos dos princípios de resistência e retenção para restaurações Classe IV, apresentados por CORREA ${ }^{23}$ a- aplicação de força oblíqua tende a deslocar a restauração b- cauda-de-andorinha c- degrau incisal para reduzir o deslocamento

ROBERTS; MOFFA, ${ }^{70}$ em 1972, mencionaram que a restauração estética de ângulo incisal fraturada constituía-se numa das maiores dificuldades clínicas e que, no passado, este tipo de restauração era complicado por dois motivos:

1)- falta de material restaurador adesivo 
2)- presença de uma câmara pulpar ampla em pacientes jovens, o qual limitava seriamente o preparo da cavidade necessária para obter retenção e estabilidade adequada.

Ressaltaram também algumas vantagens de um novo material restaurador composto sobre os anteriormente usados: baixa contração de polimerização; expansão térmica mais próxima do dente pela incorporação de partículas minerais e de óxidos, maior dureza e resistência à abrasão. Disseram ainda que o recente avanço na área de adesivos mostrou que o condicionamento ácido do esmalte aumenta consideravelmente a rugosidade superficial e a adesão destes agentes à estrutura dental.

A partir de um caso clínico em dente anterior fraturado, relataram a utilização do condicionamento ácido e adesivo para retenção em restauração com resina composta sem a necessidade de pinos ou de outra preparação cavitária. A técnica descrita por eles tem sido usada em dentes anteriores com ângulo fraturado, obtendo resultados satisfatórios.

HINDING ${ }^{46}$, em 1973, ressaltou o desenvolvimento de uma técnica empregando um preparo cavitário sinuoso que era restaurado com resina acrílica e condicionamento ácido. O condicionamento ácido, segundo o autor, aumenta a retenção mecânica da resina, proporcionando uma restauração com estética por período superior a dois anos. As características do modo de preparar dentes com perda do ângulo incisal por fratura podem ser vistas na figura 4.

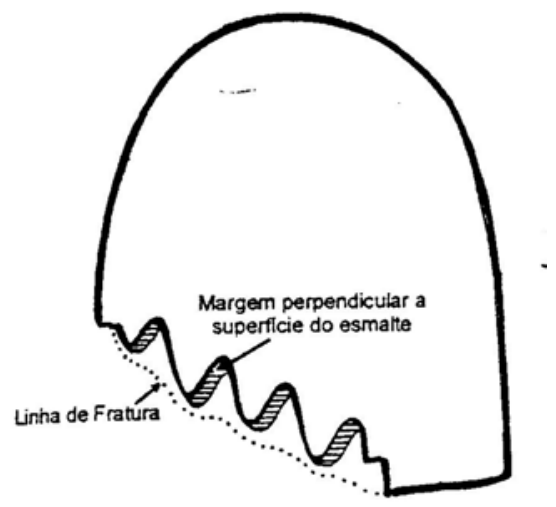

FIGURA 4 - Preparo com sinuosidades para fraturas de ângulos de HINDING ${ }^{46}$ 
Mencionou que a qualidade da retenção destas restaurações varia diretamente com a quantidade de esmalte exposto e inversamente ao tamanho da restauração. No entanto, a eficácia é mais provável quando a proporção do esmalte/resina for alta. Esta técnica não é indicada em restaurações freqüentemente submetidas a severas forças mastigatórias.

STARKEY; AVERY ${ }^{79}$, em 1973, relataram um preparo cavitário para dentes anteriores fraturados com perda somente de um ângulo incisal com um ombro de aproximadamente $1 \mathrm{~mm}$ de largura em todo o perímetro da cavidade e executar irregularidades (ombro escalonado) na margem vestibular para harmonizar esteticamente a restauração com a estrutura dental (Figura-5); a técnica restauradora empregada na época foi o condicionamento ácido e a resina acrílica Sevriton..

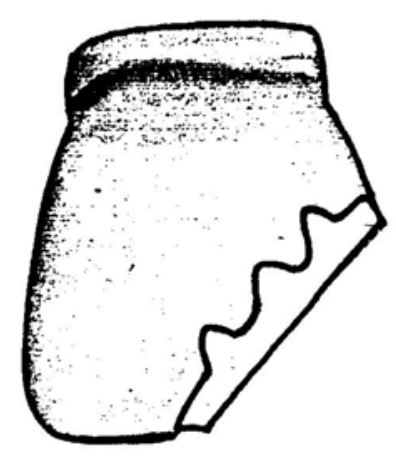

FIGURA 5 - Cavidade Classe IV com ombro escalonado

Segundo os autores, para este tipo de restauração a estética se mantinha por três a quatro anos, em função da borda incisal estar exposta ao estresse e à abrasão, necessitando assim de substituição periódica. Concluíram que este tipo de preparo cavitário evitava a execução de uma coroa de jaqueta.

ERIKSEN; BUONOCORE ${ }^{34}$, em 1976, avaliaram cinco tipos diferentes de cavidades Classe $\mathrm{V}$ realizadas nas superfícies vestibulares de molares 
(Figura 6) e sua relação com a infiltração marginal com exceção do grupo A, no qual em metade dos dentes a infiltração marginal era avaliada logo após o término do polimento, nos demais grupos (B-E) e no restante do grupo $A$ a infiltração marginal era avaliada somente depois da termociclagem, realizada por uma hora com intervalos de 1 minuto e banhos térmicos variando de $0{ }^{\circ} \mathrm{C}$ a $60{ }^{\circ} \mathrm{C}$. Embora algumas restaurações com as margens de esmalte biseladas tenham apresentado um leve grau de infiltração marginal após a termociclagem, concluíram que os valores encontrados indicaram que esta técnica poderia prevenir a infiltração marginal. A presença do bisel pode ser benéfica porque as margens das restaurações podem ser mais facilmente definidas.

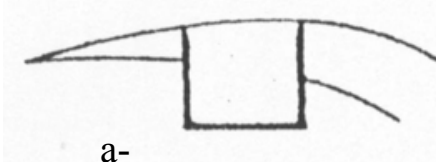

a-

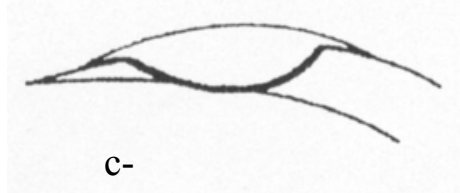

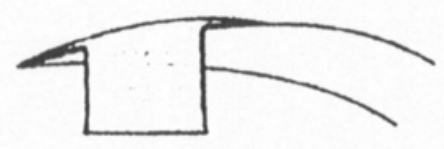

b-

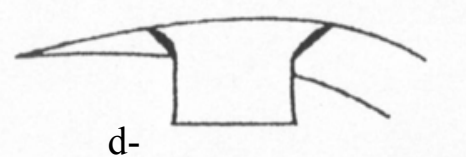

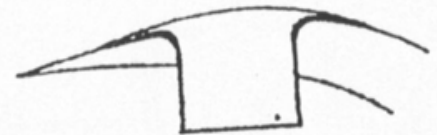

e-

FIGURA 6 - Esquema das cavidades empregadas por ERIKESEN, BUONOCORE ${ }^{34}$
a)- sem bisel ("butt joit")
b)- borda fina ("feather edged")
c)- configuração rasa ("saucer shaped")
d)- margens biseladas ("funnel shaped")
e)- tipo diferente de borda fina ("featheredged")

O efeito do biselamento na ocorrência de fraturas de prismas fragilizados circundadas por esmalte e restauradas com resina composta foi pesquisado por OILO; JORGENSEN ${ }^{62}$, em 1977. Cento e cinco cavidades Classe $\mathrm{V}$ em dentes humanos foram preparadas com alta rotação, empregando uma ponta diamantada esférica sob refrigeração abundante. As cavidades tinham aproximadamente $2 \mathrm{~mm}$ de diâmetro por $2 \mathrm{~mm}$ de profundidade. Quinze cavidades foram preparadas para formarem um ângulo 
cavossuperficial de $90^{\circ}$ (sem bisel). Em 45 cavidades, com uma ponta diamantada fina em forma de chama, foram executados biséis de 0,25 - 0,5 $\mathrm{mm}$ de extensão Nas demais 45 cavidades também foram realizados os biséis, apresentando somente uma variação na extensão que foi de 0,5 - 1,0 $\mathrm{mm}$ (Figura 7).

Os dentes depois de extraídos foram armazenados em uma solução aquosa de cloramina a $0,2 \%$ e, depois de preparados, foram armazenados em água deionizada a $37^{\circ} \mathrm{C}$ por no mínimo duas horas. As cavidades com 1 - $2 \mathrm{~mm}$ de esmalte circunjacente foram condicionadas a uma solução de ácido fosfórico a 35\%, por um minuto e meio, e depois lavadas, secas e restauradas com três diferentes tipos de materiais restauradores. Dez minutos após o término do procedimento restaurador os excessos eram removidos e, depois do polimento, uma gota de azul de metileno (3\% solução aquosa) era colocada ao redor da restauração por um minuto. Os dentes então eram lavados e inspecionados por meio de lupa estereoscópica.

Os autores concluíram que as fraturas ocorreram em todos os tipos de cavidades e com todos os materiais restauradores. Porém, algumas diferenças foram encontradas: a) quase todas as cavidades com o ângulo cavossuperficial em $90^{\circ}$ (sem bisel), apresentaram fraturas nas margens de esmalte; b) em todos os materiais, o aumento da largura do bisel ocorreu diminuição de fraturas nas margens de esmalte.

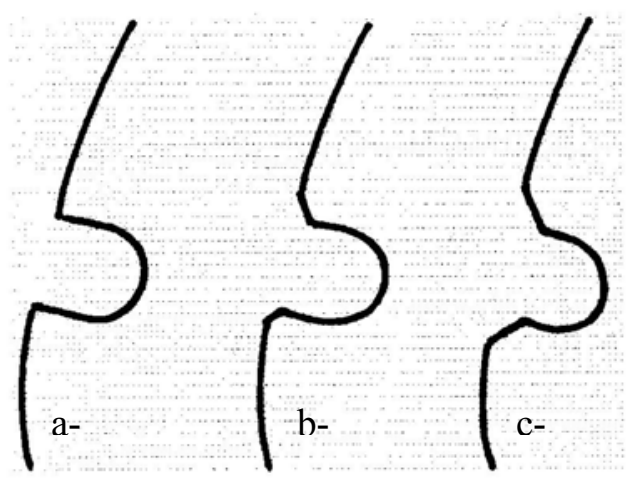

FIGURA 7 - Desenho esquemático da variação do bisel nas cavidades apresentadas por OILO; JORGENSEN ${ }^{62}$
a)- sem bisel
b)- bisel de $0,25-0,5 \mathrm{~mm}$
c)- bisel de 0,5-1,0 $\mathrm{mm}$ 
ELIASSON; HILL ${ }^{33}$, em 1977, analisaram o preparo de ângulos cavossupeficiais existentes e suas relações com a infiltração marginal de resinas compostas. Cavidades de Classe V foram preparadas em 180 dentes humanos extraídos cujo ângulo cavossuperficial tinha cinco diferentes configurações: (I e II) terminação em $90^{\circ}$; (III) margens em $90^{\circ}$ apresentando um sobre-contorno do material restaurador, (IV) bisel formando um ângulo de $45^{\circ}$; bisel côncavo com margem de $90^{\circ}$ e bisel côncavo com margem de $140^{\circ}$ (Figura 8). Trinta cavidades com terminação em $90^{\circ}$ (sem bisel) foram restauradas com resina Concise sem o condicionamento ácido, servindo como grupo controle. As restantes foram restauradas com a mesma depois do esmalte ter sido condicionado com ácido e aplicado o adesivo. As restaurações foram polidas, com exceção de um grupo de 30 dentes em que a resina foi sobreposta, isto é, colocada 1 - $2 \mathrm{~mm}$ além do ângulo cavossuperficial de $90^{\circ}$ ("feather edge"). A metade dos espécimes de cada grupo foi submetida a 2500 ciclos térmicos entre $10{ }^{\circ} \mathrm{C}$ e $60{ }^{\circ} \mathrm{C}$. A infiltração ao redor das restaurações foi avaliada por meio de auto-radiografia com isotopo radioativo de cálcio. Chegaram à conclusão de que o padrão de infiltração foi o mesmo para todos os modelos de margem cavossuperficial.

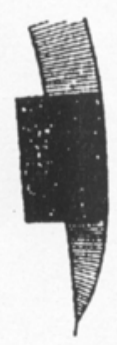

GRUPOS I \& II

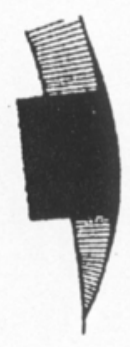

III

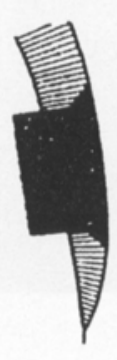

IV
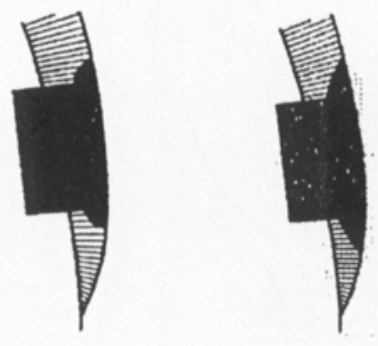

VI

FIGURA 8 - Variações de tratamento do ângulo cavossuperficial, testados por ELIASON; HILL ${ }^{33}$ 
Em 1977, YATES; HEMBREE ${ }^{84}$ afirmaram que muitos profissionais estavam utilizando o condicionamento ácido sem qualquer preparo cavitário ou retenção auxiliar e realizaram estudo para comparar a resistência à fratura de restaurações Classe IV com condicionamento ácido, com e sem retenção usando os sistemas Nuva, Concise e a resina Restodent.

Utilizaram 60 incisivos centrais superiores recém-extraídos, nos quais foram criadas fraturas com $5 \mathrm{~mm}$ de extensão no sentido mesio-distal, $6 \mathrm{~mm}$ cervico-incisal e $1 \mathrm{~mm}$ de bisel no ângulo cavossuperficial. O segundo grupo foi preparado da mesma forma do primeiro, exceto um sulco retentivo em dentina com broca 33 e 1/2.

Após restauração e aplicação de força na borda incisal da restauração a $45^{\circ}$, constataram que entre as amostras em que se utilizou somente ataque ácido e ácido mais retenção, as médias destas foram consideravelmente maiores. Concluíram que:

- em restaurações Classe IV de dentes fraturados poderá ser utilizado algum tipo de sulco retentivo para aumentar a resistência à fratura;

- pesquisas deverão ser realizadas para determinar a relação da configuração do preparo e a resistência compressiva e de união de diferentes materiais.

DENEHY; DOERING; TORNEY ${ }^{29}$, em 1980, relataram que o sucesso de uma restauração Classe IV com condicionamento ácido depende de espessura adequada de esmalte nas faces vestibular e lingual, sendo, para isso, um bisel recomendado. Pois o profissional irá normalmente executar um bisel na vestibular, omitindo-o na lingual devido ao contorno e à dificuldade de acesso. Portanto, se os incisivos inferiores contactarem em cêntrica, próximo da fratura e na presença de pouco ou nenhum bisel, o resultado será um inadequado sobrepasse de resina após o ajuste oclusal. Mesmo que se realize um sobrepasse na margem lingual, poderá não ser de espessura suficiente para proporcionar adequada retenção e prevenir o 
deslocamento da restauração. Onde um profundo e extenso bisel poderá ser realizado para proporcionar a quantidade necessária de resina composta.

BAGHERI; DENEHY ${ }^{3}$, em 1983, pesquisaram o efeito da extensão do bisel e da extensão de fratura Classe IV restauradas com resinas compostas e retidas pelo condicionamento ácido em 70 incisivos centrais superiores recém-extraídos que tiveram as faces mesial e distal reduzidas para produzirem paralelismo à largura mesio-distal de $7 \mathrm{~mm}$ e a incisal reduzida no sentido vestíbulo-lingual à espessura de $3 \mathrm{~mm}$.

Os dentes foram divididos em dez grupos variando o comprimento do bisel em 1, 2 e 3 mm, e o da restauração em 2, 3 e 4 mm, tendo como grupo controle margem em $90^{\circ}$ e restaurações com $3 \mathrm{~mm}$ de comprimento.

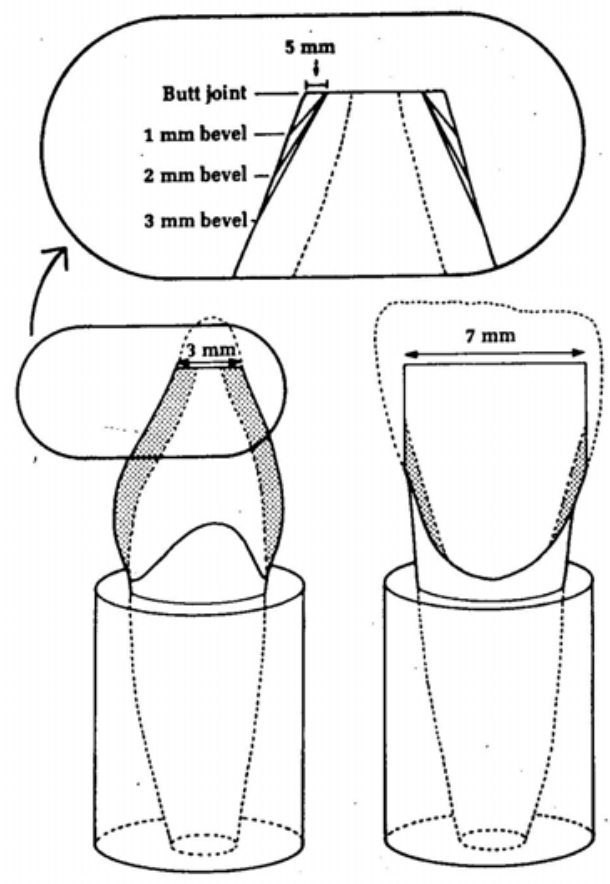

FIGURA 9 - Desenho esquemático da extensão e do comprimento do bisel, BAGHERI, DENEHY ${ }^{3}$

Cinco minutos após a realização da restauração, foi acabada/polida e armazenada em água por oito dias para a realização dos experimentos à 
uma inclinação de $45^{\circ}$ a $5 \mathrm{~mm} / \mathrm{min}$, com célula de carga de $500 \mathrm{~kg}$. Obtiveram os seguintes resultados:

- o bisel do esmalte aumentou significativamente a resistência de união da resina composta ao esmalte condicionado;

- aumento do comprimento do bisel acima de $1 \mathrm{~mm}$ não produz resistência adicional;

- resistência de união diminuiu significativamente quando o comprimento da restauração aumentou, restaurações longas são mais suscetíveis a deslocamentos. Salientaram que o profissional poderá maximizar retenções com restaurações longas e minimizar o contato incisal para evitar o seu deslocamento.

PORTE; et al. $^{65}$, em 1984, realizaram um estudo sobre resinas compostas em quatro formas cavitárias: (A) cavidades com margens em $90^{\circ}$ ("butt joint"); (B) cavidade experimental; (C) cavidades com bisél côncavo; (D) cavidades com um longo bisel; (Figura 10). As margens cavitárias eram examinadas por meio de microscópio eletrônico de transmissão. Depois da termociclagem , alguns exemplos de cada forma de cavidade foram expostos à solução [ ${ }^{45} \mathrm{Ca}$ ] $\mathrm{Cl}_{2}$ e a quantidade de infiltração avaliada.

Baseadas na penetração do $\mathrm{Ca}^{45}$ e na análise quantitativa da micromorfologia da adaptação marginal, a cavidade experimental e as cavidades com longo bisel apresentaram melhores margens e valores menores de infiltração marginal.
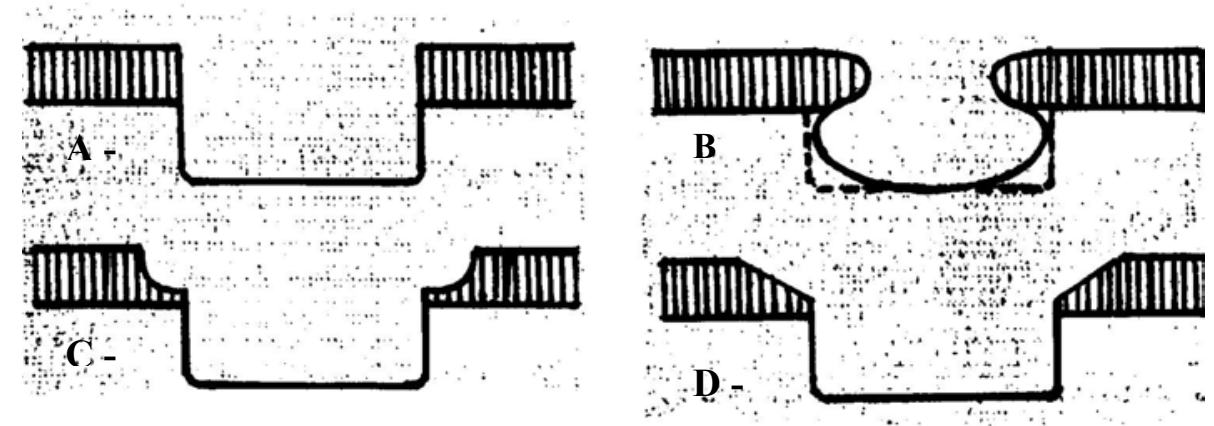

FIGURA 10 - Formas cavitárias ensaiadas por PORTE et al ${ }^{65}$

A - Margens em $90^{\circ}$ ("Butt joint") B - Cavidade experimental

C - Bisel côncavo

D - Bisel longo 
Para identificar os materiais e a técnica ensinada em escolas dos EUA e Canadá devido à diversidade de abordagens para restaurações em dentes anteriores, HARDISON ${ }^{45}$, em 1987, realizou uma pesquisa sobre Classe III e IV em resina composta, enviando questionários para a disciplina de Dentística de 67 faculdades.

Questionário de questões e respostas:

- Classe III - Preparo se estende da área de contato não ultrapassando a borda superior do terço gengival da área proximal. O esmalte do ângulo incisal apresenta-se com esmalte suportado. A preparação pode ser vista pela vestibular, mas não atinge a linha do ângulo, por lingual a preparação não se estende além da crista marginal. Axialmente se estende aproximadamente $1 \mathrm{~mm}$ em dentina.

- Classe IV - mesmos parâmetros aplicados acima, exceto o terço incisal que está envolvido em classe IV. A cavidade pode ser estendida sobre a crista marginal lingual.

Constatou que dez escolas especificaram que nunca recomendam pinos para restaurações de Classe IV ou que evitam. Sintetizou que muitas faculdades combinam a técnica do condicionamento ácido a macrorretenções, para proporcionar retenção, e são favoráveis ao biselamento maior do que $1 \mathrm{~mm}$ para Classe IV.

DARVENIZA $^{27}$, em 1987, mencionou ser aceitável que a melhor forma de retenção, resistência às forças verticais para restaurações de Classe IV de resina composta seja desenvolvida pela união micromecânica proveniente do condicionamento ácido. Todavia, a forma de resistência, resistência às forças oblíquo-apical, não tem sido tão discutida. Como resultado, algumas resinas compostas fraturam no ângulo incisal e o deslocamento da restauração tem sido freqüentemente atribuído às insuficientes propriedades físicas das resinas ou condicionamento ácido mal executado no esmalte. Apresentou configurações cavitárias para restaurar Classe IV com pequena e grande perda de tecido, mostradas nas figuras 11 e 12. 


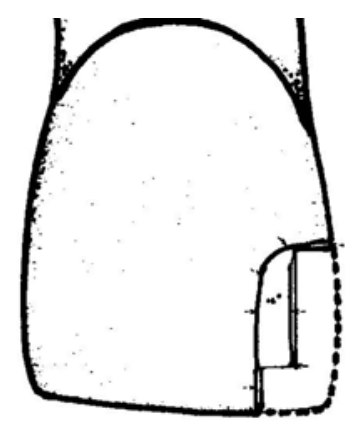

(a)

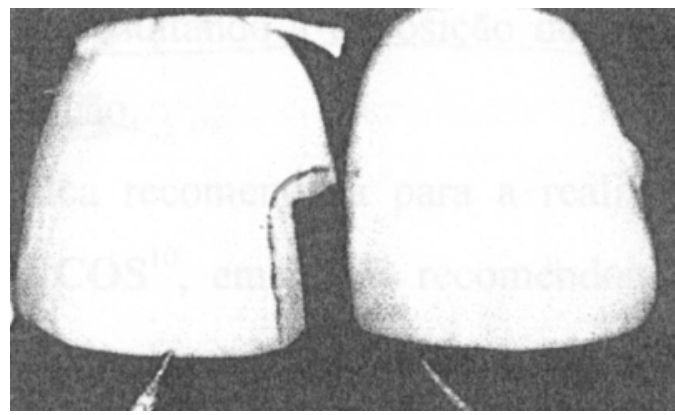

(b)

FIGURA 11 - Esquema de cavidade preparada: (a) com bisel de $1 \mathrm{~mm}$ de largura indicada para Classe IV com pequena perda tecidual; (b) aspecto clínico da cavidade preparada, DARVENIZA ${ }^{27}$

Demonstrou que o preparo com configuração conservativa é empregado para cavidade Classe IV com pequena perda de estrutura no sentido mesio-distal, recebendo pouca ou moderada força incisal (Figura 11). Realizou,

após eliminação da cárie, um bisel com $1 \mathrm{~mm}$ de largura e $1 \mathrm{~mm}$ de profundidade no esmalte e um aplainamento da parede gengival.

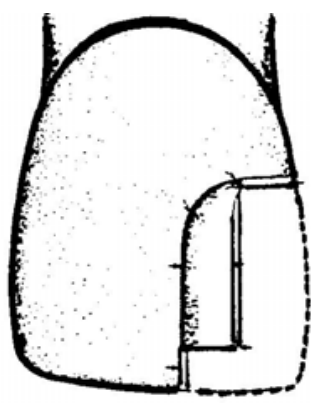

(a)

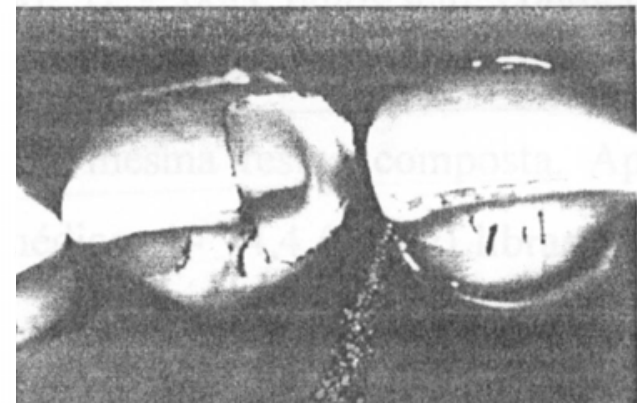

(b)

FIGURA 12 - Esquema para cavidades extensas de Classe IV (a) e vista incisal da cavidade concluída (b), DARVENIZA ${ }^{27}$

A cavidade da figura 12 evita a necessidade de pinos em cavidades de Classe IV extensas no sentido mesio-distal e/ou submetidas à grandes forças incisais ou com histórias de repetida falhas. Nas restaurações, após a 
remoção da cárie um bisel vestibular e lingual foi realizado correspondendo a perda de estrutura no sentido mesio-distal. Ressaltou que esta preparação (Figura 12) evita o uso de pinos, e suas desvantagens: o escurecimento do pino, perda da resina composta, resultando em exposição do pino; trincas no dente, e enfraquecimento da restauração.

SMITH; HOOD; STOKES ${ }^{75}$, em 1990, estudaram a influência da configuração do ângulo cavossuperficial na resistência à fratura sobre o impacto em restaurações Classe IV realizadas com resina composta. Cinquenta incisivos centrais foram selecionados e posicionados de forma a receberem um impacto na porção incisal visando, além de fraturar o dente, padronizar a fratura. Em seguida, os mesmos dentes eram restaurados, posicionados e recebiam um novo impacto para que a fratura ocorresse, sendo registrados os valores necessários para que a fratura fosse proporcional tanto aos dentes intactos quanto aos restaurados. Por fim, nestes mesmos dentes um bisel era realizado ao redor do ângulo cavossuperficial, e posteriormente eram novamente restaurados e posicionados de forma a receberem um último impacto, tendo os valores também registrados.

A partir dos valores registrados, os autores concluíram que a resistência ao impacto de dentes restaurados com presença de bisel foi significativamente maior que os dentes restaurados com ausência de bisel e que as diferenças na resistência ao impacto entre os dentes intactos e os dentes restaurados com presença de bisel não foram significativas.

SMALES $^{74}$, em 1991, pesquisou por aproximadamente 16 anos restaurações de resina composta realizadas com e sem o efeito do condicionamento do esmalte. As restaurações foram avaliadas pelo método de colocação do material (Concise, Concise Enamel - Bonding), tipo da cavidade (Classe III, IV, V) e idade do paciente $(10-20,21-40,41-60,+60$ anos). A resina Concise foi inserida com e sem o condicionamento ácido e com agente de união. As restaurações foram realizadas por diferentes 
dentistas e estudantes supervisionados. As margens foram biseladas e condicionadas com ácido fosfórico a 37\%, sendo as restaurações com Concise realizadas desde 1971 e com adesivo Concise Enamel - Bonding desde 1974. As falhas resultaram de fraturas, mobilidade, reparo ou substituição de restauração e cárie marginal. Notou que a classe da cavidade afeta substancialmente a longevidade da resina composta, pois $50 \%$ das restaurações de Classe IV duraram simplesmente 4,07 \pm 0,62 anos. Dentre as 950 restaurações verificadas, 94 eram de Classe IV, sendo que de 19 a $20 \%$ destas requereram pinos; houve consideravelmente mais falhas com as restaurações Classe IV em pacientes idosos e, dentre nove restaurações a pino que falharam, cinco eram de Classe IV. Assim, o desgaste, o estresse por bruxismo e o aumento da perda de dentes podem comprometer restaurações Classe III e IV.

TAN; TJAN $^{80}$, em 1992, avaliaram a resistência à fratura de restaurações Classe IV de resina composta preparadas sem bisel, com bisel e chanfradas. Setenta incisivos centrais intactos, tendo aproximadamente o mesmo tamanho, foram divididos aleatoriamente em sete grupos: sem bisel (controle), biselados num ângulo de $45^{\circ}$ com extensão de 1 e 2 mm; biselados num ângulo de $60^{\circ}$ com extensão de 1 e $2 \mathrm{~mm}$; e chanfrados com extensão de 1 e $2 \mathrm{~mm}$. Foram restaurados com uma resina composta híbrida e avaliados na máquina de teste universal Instron de compressão em um eixo axial de $45^{\circ}$. A análise estatística indicou que não houve diferença significante entre o grupo de controle e os grupos biselados e chanfrados de $1 \mathrm{~mm}$, mas os grupos com margens biseladas e chanfradas de $2 \mathrm{~mm}$ produziram um aumento na resistência a fratura. Este estudo também mostrou que não há diferença significativa nos valores de resistência à fratura entre o bisel e o chanfrado.

HALL; COCHRAN; SWARTZ ${ }^{44}$, em 1993, estudaram in vitro sobre a microinfiltração marginal em 60 restaurações Classe $V$, em relação às cavidades e sua localização da junção cemento-esmalte (JCE). Com quatro 
grupos de 15 dentes cada, foram preparados com a margem cervical terminada da seguinte forma:

- margem sem bisel ("butt joint"), localizada aproximadamente a $1 \mathrm{~mm}$ acima da JCE;

- margem biselada, localizada aproximadamente a $1 \mathrm{~mm}$ acima da JCE;

- margem sem bisel ("butt joint"), localizada aproximadamente a 1,5 mm acima da JCE;

- margem biselada, localizada aproximadamente a 1,5 $\mathrm{mm}$ acima da JCE.

Os dentes foram condicionados, tratados com um agente de união e restaurados com resina composta. Posteriormente, foram seccionados e analisados por meio de autoradiografia. Os resultados permitiram a conclusão de que as margens sem bisel localizadas aproximadamente a 1 $\mathrm{mm}$ acima da JCE tiveram significativamente mais infiltração marginal do que os grupos restantes, indicando que as margens de esmalte de cavidades Classe $\mathrm{V}$ a serem restauradas com resina composta devem ser biseladas para reduzirem a microinfiltração independente da localização da JCE.

GRIEVE; SAUNDERS; ALANI ${ }^{40}$, em 1993, avaliaram o efeito do bisel em cavidades Classe $V$ por período de 2 anos. Os autores observaram que o biselamento das cavidades permitiu a ocorrência de uma significativa redução na infiltração quando comparado com as cavidades não biseladas.

Segundo CRISPIN ${ }^{25}$, em 1994, as margens de esmalte em cavidades a serem restauradas com resinas compostas devem normalmente terminar com o bisel. $\mathrm{O}$ biselamento das margens de esmalte aumenta a área a ser condicionada, a retenção e a resistência à infiltração marginal. O término dos prismas de esmalte é exposto como resultado do biselamento, que proporciona orientação dos prismas de esmalte para o condicionamento 
ácido. O bisel também permite que haja uma gradual transição na margem entre a resina composta e a estrutura dentária, fazendo com que as margens sejam mais difíceis de ser detectadas visualmente. Os biséis num ângulo de $45^{\circ}$ com largura de 1 a $2 \mathrm{~mm}$ são geralmente empregados em áreas visíveis por vestibular, sendo usados biséis mais curtos, normalmente de 0,5 mm em outras áreas. Conforme o autor, exceções ao uso do bisel em margens de esmalte incluem casos em que o acesso para o bisel irá estender a forma cavitária nas margens proximais em contato com o dente adjacente e em margens de cavidades Classe I, II e III sujeitas à função oclusal.

CHAN; COOLEY ${ }^{19}$, em 1996, mencionaram que restaurações de Classe IV são comuns por fratura traumática de ângulo incisal e as induzidas por cárie são comumente grandes lesões de Classe III que solapam o ângulo incisal.

Para lesões de Classe IV, a cavidade segue a forma convencional das preparações para Classe III e inclui a porção do ângulo incisal. A cárie e o esmalte enfraquecidos são removidos e a margem deve ser biselada (Figura 13), sendo que para fratura em que não existe cárie ou envolvimento pulpar o bisel é freqüentemente a preparação necessária. Geralmente pinos retentivos não são necessários em razão da técnica adesiva prover suficiente adesão para a restauração. Constataram que um recente estudo, referenciando NEUMEYER ${ }^{61}$, concluiu a existência de somente $10 \%$ de aumento na resistência à fratura de restaurações de Classe IV a pinos associados à técnica de condicionamento ácido. Ainda salientaram que alguns clínicos discutem que, se a adesão falhar, é melhor a perda da restauração do que esta ficar confinada ao local pelos pinos. E admitiram que em raras situações, quando existir pouco esmalte disponível para a adesão e a resina composta for o único tratamento viável, pinos podem ser usados como retenção adicional. 

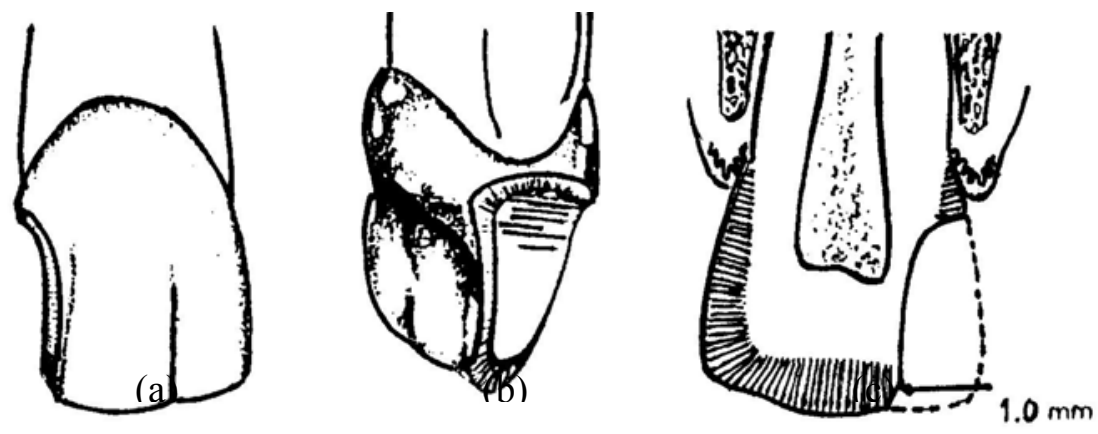

FIGURA 13 (a)- Vista vestibular $\quad$ (b)- próximal $\quad$ (c)- secção mesio-distal Cavidades Classe IV para utilização da técnica do condicionamento ácido como meio de retenção, CHAN; COOLEY ${ }^{20}$

De acordo com BUSATO ${ }^{13}$, em 1997, o uso do bisel ocorre em função de aumentar a força de união das resinas compostas ao esmalte condicionado; possibilitar a exposição dos prismas de esmalte transversalmente, os quais desta forma fornecem um melhor padrão de condicionamento; possibilitar a exposição de uma camada de esmalte mais energética; promover melhor selamento marginal; e aumentar a área disponível para o ataque ácido. Possibilita também a transição gradual de espessura do material restaurador resinoso para o dente, proporcionando uma estética melhor.

CARVALHO $^{17}$, em 1998, constatou que em casos da retenção relevante, como em restaurações de Classe IV extensas no sentido incisogengival, principalmente em que os movimentos excursivos da mandíbula ocorrem sobre a área a ser restaurada, pode-se assegurar a retenção por meio de recursos operatórios, como extensão de bisel para $2 \mathrm{~mm}$ e/ou colocação de pinos rosqueáveis em dentina.

Conforme GALAN Jr \& NAMEN ${ }^{37}$, em 1998, a redução e eliminação da linha demarcatória entre o ângulo cavossuperficial da cavidade e a resina 
restauradora são determinadas pela extensão e profundidade do bisel ou chanfro aplicado. Atualmente, tem-se demonstrado que o bisel ou chanfro não só melhora o encontro estético da resina composta com o dente como também expõe as cabeças dos prismas de esmalte do cavossuperficial para aumentar a retentividade produzida pelo condicionamento ácido do esmalte e a resina intermediária. Quanto mais liso for o bisel ou chanfro, melhor será a adaptação da resina composta e menor o estresse sobre a resina.

Em 2000, CARVALHO et al. ${ }^{18}$, pesquisaram o efeito da orientação dos prismas na resistência à tração do esmalte. Oito terceiros molares, livres de cáries, foram usados após serem limpos com pedra pomes e água. Toda superfície de esmalte foi condicionada com ácido fosfórico a $37 \%$ por 30 segundos, seca , e aplicado o sistema adesivo Single Bond. Várias camadas de resina composta (Z-100) foram inseridas incrementalmente sobre a coroa, formando uma estrutura de aproximadamente $5 \mathrm{~mm}$ de espessura sobre toda a coroa dos dentes. Os dentes foram armazenados por 24 horas em água a $37{ }^{\circ} \mathrm{C}$, e depois as coroas serialmente seccionadas verticalmente na direção mésio-distal para obter vários cortes de $0,7 \mathrm{~mm}$ de espessura. As secções eram divididas ao meio e em cada metade um trimmed foi suavemente feito, em ambos os lados, com uma ponta diamantada para reduzir a área de esmalte a ser seccionada, tanto na vertente externa como na vertente funcional. $O$ trimmed foi executado nos espécimes para permitir o teste no esmalte, estando os seus prismas tanto orientados paralelamente $(P L)$ ou perpendicularmente (PD) à força aplicada. Os espécimes foram fixados e estressados numa tensão de $0,5 \mathrm{~mm} / \mathrm{min}$. As imagens do SEM foram tiradas das superfícies fraturadas para examinar o local da fratura e para confirmar a orientação dos prismas de esmalte. A resistência média à tração do esmalte com os prismas dispostos paralelos à tensão aplicada foi $24,7 \pm 9,6 \mathrm{MPa}$, e 11,4 \pm 6,3 $\mathrm{MPa}$ para os prismas dispostos perpendicularmente. Concluíram que a resistência à tração do esmalte depende da orientação dos prismas de esmalte. 
HOELSCHER, et al. ${ }^{47}$, em 2000, avaliaram a presença ou ausência do bisel na face vestibular, em relação à adaptação das margens vestibulares em restaurações Classe III de resina composta, preparadas nas superfícies mesiais e distais de incisivos. Nas margens das faces vestibulares, linguais e gengivais de 20 preparos um bisel de $0,5 \mathrm{~mm}$ foi executado. As margens linguais e gengivais, mas não as vestibulares, também foram biseladas nos outros 20 preparos. Todas as restaurações foram polidas e armazenadas numa umidade de $100 \%$ a $37{ }^{\circ} \mathrm{C}$, sendo depois termocicladas a uma variação de temperatura de $4{ }^{\circ} \mathrm{C}$ a $55{ }^{\circ} \mathrm{C}$, com 30 segundos de banho por 500 ciclos. Os corpos-de-prova foram imersos numa solução de $50 \%$ de nitrato de prata, posteriormente seccionados e a microinfiltração avaliada. Os pesquisadores concluíram, que os exemplares preparados sem o bisel vestibular revelaram uma significativa maior infiltração marginal do que os preparos que receberam o bisel vestibular.

O efeito da penetração de corantes através das margens, em que um bisel com $45^{\circ}$, foi avaliado em 2000 por $\mathrm{KANCA}^{50}$. Oitenta molares recentemente extraídos foram usados no estudo. Preparo Classe I de aproximadamente $4 \times 4 \mathrm{~mm}$ foi realizado nos dentes. Na metade dos dentes as margens de esmalte foram desgastadas para formar um ângulo de $90^{\circ}$ com a superfície externa do dente, na outra metade as margens eram formadas deixando os prismas de esmalte dispostos transversalmente num ângulo de $45^{\circ}$. Todos os dentes foram condicionados e, em seguida, um sistema adesivo simplificado (One step) foi usado. Divididas igualmente em grupos, as resinas compostas Silux, Herculite, Heliomolar e Z-100 foram inseridas em dois incrementos e fotoativados por 20 segundos. As restaurações foram polidas e imersas em fucsina básica por 24 horas. O autor concluiu que o bisel de $45^{\circ}$ nas margens de esmalte do ângulo cavossuperficial foi muito efetivo na redução da penetração do corante. 
De acordo com SILVA e SOUZA Jr; CARVALHO; MONDELLI; ${ }^{76} \mathrm{em}$ 2000, um ponto de muita importância em um preparo cavitário em dentes anteriores para ser restaurado com sistema adesivo/resina composta é a forma e a qualidade de seu término. Executar um bisel em todo o ângulo cavossuperficial, além de assegurar melhor vedamento da cavidade, auxilia muito a harmonização estética. A disposição do bisel, no entanto, pode variar. Quando não houver alteração de cor da estrutura dentária interna, a espessura e a extensão da resina na área de bisel não precisam ser muito grandes. Por outro lado, em situações em que se percebe escurecimento interno da estrutura dentária deve-se aumentar a espessura e extensão do bisel para facilitar e mascarar essas alterações e conseguir um resultado estético mais satisfatório. Num bisel mais profundo e extenso consegue-se aplicar uma camada mais espessa de resina e dissimular satisfatoriamente a descoloração sem causar sobre-contorno na restauração.

BARATIERI et al. ${ }^{5}$, em 2001, afirmou que em preparo cavitário para Classe $\mathrm{V}$ a execução do bisel tem apenas a vantagem de auxiliar na obtenção de melhor estética, uma vez que ele geralmente possibilita a obtenção de uma "fusão" entre a resina e a estrutura dental. Todavia, alguns autores atribuem a ele as seguintes vantagens adicionais: ${ }^{8,9,32,41,42}$.

- Aumento da área superficial para o condicionameto ácido;

- Possibilita a remoção da camada superficial do esmalte externo rica em flúor, aprismática e, por conseqüência, menos energética;

- Possibilita a obtenção de um padrão de condicionamento mais homogêneo;

- Proporciona melhor adaptação marginal e, por conseguinte, menos infiltração.

Uma outra questão importante diz respeito às restaurações já existentes e que precisam, por alguma razão, serem substituídas. Nesses casos o preparo deverá limitar-se à remoção da restauração fracassada e do tecido cariado, caso este esteja presente. Quanto à necessidade de 
execução de um bisel para estes casos, deve-se levar em conta os mesmos fatores descritos para as lesões primárias. No entanto, caso a restauração fracassada tenha sido executada em uma cavidade biselada, o bisel deverá ser redefinido e mantido. Para remover a restauração fracassada, devem ser utilizadas pontas diamantadas esféricas em alta velocidade. Algumas vezes, poderá ser vantajoso e conveniente remover apenas a parte da restauração fracassada.

Segundo BUSATO; HERNANDEZ; MACEDO ${ }^{14}$, em 2002, a retenção e a forma de resistência são adquiridas com a hibridização ou a integração com a lama dentinária, em que é dispensado o preparo cavitário convencional. E nas margens de esmalte para as cavidades Classe III e V poderá ou não ser executado o bisel.

De acordo com CHAIN; RODRIGUES ${ }^{20}$, em 2002, o bisel deve ser executado em esmalte na maioria das restaurações porque associando o condicionamento ácido com o bisel teria vantagens como:

a)- o bisel muda a orientação dos prismas de esmalte, que freqüentemente estão dispostos paralelamente uns aos outros e quase perpendicularmente à superfície externa;

b)- o bisel expõe melhor a cabeça dos prismas de esmalte, melhorando o ataque ácido;

c)- não são todos os prismas que alcançam a superfície externa, apresentando uma superfície a qual denominamos aprismática. O bisel remove esta camada, melhorando a adesão;

d)- por ser o bisel uma regularização da camada superficial do esmalte, o mesmo propicia uma estrutura mais firme, livre de imperfeições, a qual poderia fraturar-se mais facilmente quando na contração de polimerização do material restaurador;

e)- o bisel facilita a obtenção de restaurações "invisíveis", uma busca da odontologia restauradora estética. Apesar de não ser condição essencial, a restauração estética é mais previsível após a execução do bisel. 
Em 2002, MONDELLI, J. et al. ${ }^{55}$ continuaram afirmando ${ }^{54,57,58}$, que o bom acabamento das paredes de esmalte em uma cavidade Classe IV tem papel fundamental para a obtenção de melhor estética e comportamento clínico. Dessa forma, o acabamento das paredes de esmalte deve ser efetuado por meio do bisel, possibilitando remover prismas de esmalte fragilizados; expor prismas de esmalte mais perpendiculares e reativos ao condicionamento ácido, principalmente da porção mais interna; aumentar a área de superfície favorecendo a retenção do material, além de melhorar a estética da interface entre resina e estrutura dentária.

Esse acabamento pode ser estabelecido com ponta diamantada em forma de chama n. 1111, a qual possibilita um bisel de forma côncava ou chanfrada, com largura de 1 a $2 \mathrm{~mm}$, tanto por vestibular como por lingual. É preciso ter cuidado com relação à parede gengival, na qual a utilização de instrumentos rotatórios pode implicar em remoção acentuada de esmalte que, à medida que se estende para gengival, diminui em espessura. Assim , um instrumento manual poderá ser empregado quando for mínima a espessura de esmalte, possibilitando, além do acabamento da parede gengival, a determinação de uma planificação ou pequeno bisel no ângulo cavosuperficial gengival. Tendo em vista que o término em nível zero determina uma borda muito fina para a resina composta, a confecção do bisel com término chanfrado proporciona uma espessura de borda maior de resina nas margens cavitárias de modo a favorecer a integridade e o vedamento marginal por um período mais longo.
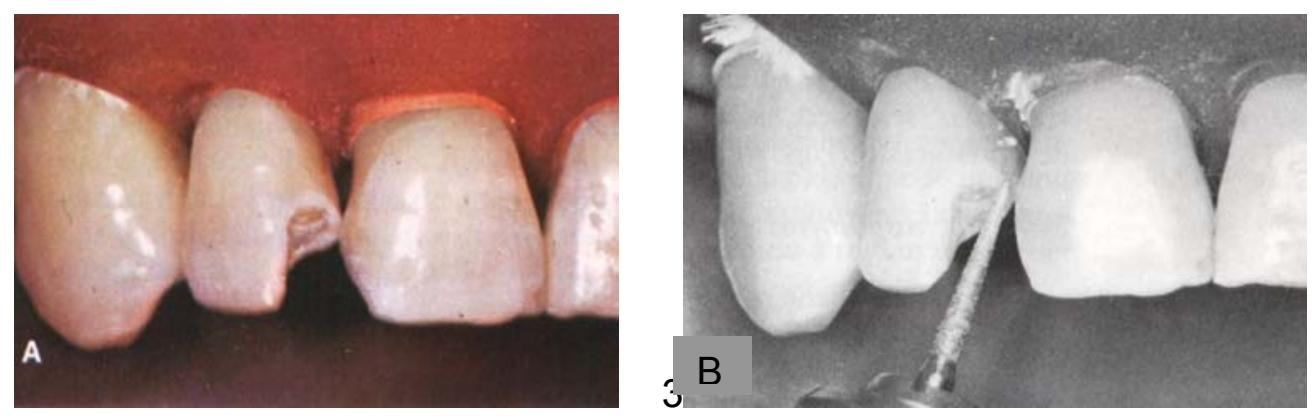

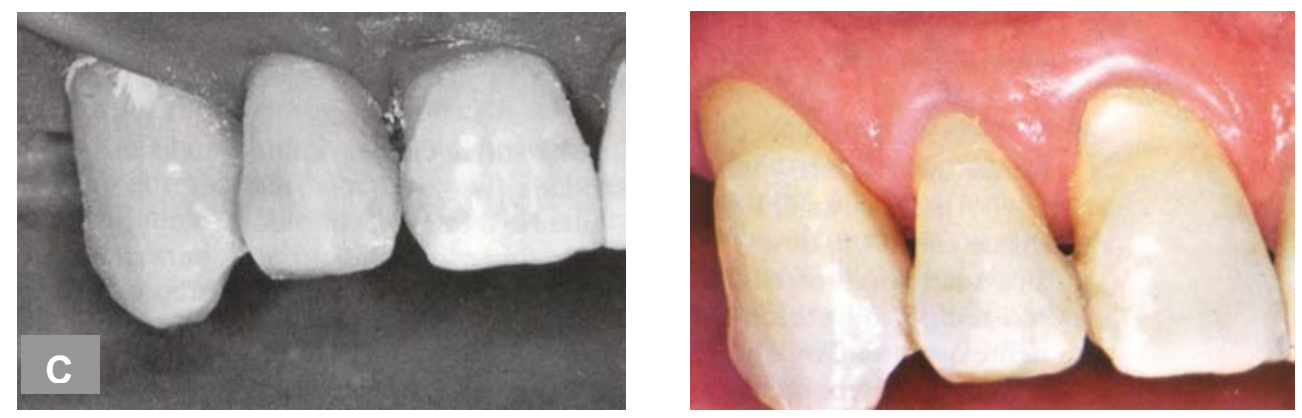

FIGURA - 14 Preparo do bisel e restauração de Classe IV, MONDELLI, J. et al. ${ }^{58}$., em 1984; com resina acrílica ativada quimicamente, no incisivo lateral superior direito. A) - Após a determinação do contorno interno e remoção do tecido cariado; B) - Ponta diamantada executando bisel periférico de forma chanfrada; C) - Aspecto da restauração antes da remoção do dique; D) - Depois da remoção deste 


\section{Abordagem Literária em Dentes Bovinos}

$\mathrm{Na}$ busca de um substituto para os dentes humanos no teste de adesão, a resistência adesiva entre dentes humanos e bovinos foi comparada por NAKAMICHI; IWAKU; FUSAYAMA ${ }^{60}$,em 1983, utilizando cimentos de policarboxilato, cimento de ionômero de vidro, fosfato de zinco e resinas compostas.

Nos dentes humanos a superfície vestibular dos incisivos centrais superiores foram desgastadas para estudo em esmalte dos primeiros molares, e expor a dentina. Para os dentes bovinos o esmalte como a dentina foi desgastado por vestibular de incisivos inferiores.

Utilizando dentes recém-extraídos com aproximadamente cinco dias e acima de seis meses. Observaram a adesão com relação ao tempo de armazenamento e à profundidade, realizando desgaste superficial e profundo.

Utilizaram as resinas compostas Adaptic e Clearfil, com seus respectivos adesivos. Confeccionaram uma matriz de $5 \mathrm{~mm}$ de diâmetro por $4 \mathrm{~mm}$ de altura a parte de resina composta para a realização do teste de tração. Obtendo as seguintes conclusões:

- embora as médias fossem ligeiramente menores com os dentes bovinos; a resistência adesiva ao esmalte não foi estatisticamente diferente entre dentes bovinos e humanos com os materiais usados;

- as médias foram menores para os dentes bovinos com qualquer um dos materiais na resistência à camada superficial, não foi estatisticamente significante entre os dentes humanos e bovinos;

- os dentes bovinos foram aprovados para as pesquisas, como substitutos de dentes humano, usando o esmalte e a dentina. Quanto à diferença de resistência entre dentes recém-extraídos e com longo período de armazenamento, os valores médios foram ligeiramente maiores nos dentes com grande período de armazenamento do que com os recémextraídos. Devido à abertura dos túbulos e pela degeneração do processo 
odontoblástico, aumentando o efeito de ancoragem nos dentes com longo armazenamento.

Segundo SAUNDERS ${ }^{72}$, em 1988, pesquisas sobre a união de resina composta à dentina, são realizados em dentes humanos extraídos e como estes tornaram-se difíceis de ser obtidos, tem sido usado dentes bovinos como alternativa aos dentes humanos em testes de resistência de união de agentes adesivos à dentina.

Comparou a resistência ao cisalhamento por impacto à camada superficial de dentina com quatro adesivos: Scothbond VLC, Topaz, Gluma e Adesivo Experimental 3M (3M exp.), utilizando dentes bovinos e humanos como substrato para determinar se estes poderão ser utilizados como alternativa em testes de união.

Após obtenção da parte de resina composta (2 $\mathrm{mm} \times 4 \mathrm{~mm})$, os espécimes, 15 para cada agente adesivo, foram termociclados (a $5^{\circ} \mathrm{C}$ e $37^{\circ} \mathrm{C}$ por 24 horas, aproximadamente 2400 ciclos) antes da realização dos testes.

Neste estudo, tinha-se conhecimento da idade dos dentes humanos e do tempo de armazenagem. Muitos dentes humanos foram extraídos por razões ortodônticas, os bovinos eram de animais jovens. Declarou que a força de cisalhamento por impacto foi utilizada neste estudo devido às forças mastigatórias serem, na maioria, de natureza de impacto.

Foram obtidos os seguintes valores, em MPa, para os dentes humanos: Scotchbond 1,36; Topaz 3,79; Gluma 14,36; 3M exp. 8,53. Para os dentes bovinos: Scotchbond 1,11; Topaz 3,92; Gluma 13,49; 3M exp. 9,96.

Relatou, ainda, que os resultados obtidos com dentes bovinos indicam que estes podem ser substitutos apropriados em estudos de resistência ao cisalhamento utilizando agentes adesivos dentinários.

A resistência de união ao cisalhamento e a microinfiltração do Scotchbond 2/Silux à dentina foram estudados por RETIEF et al. ${ }^{68}$, em 1990. A resistência de união ao cisalhamento foi determinada na dentina oclusal de 24 pré-molares humanos e 25 incisivos bovinos. Os espécimes foram armazenados em solução salina a $37{ }^{\circ} \mathrm{C}$ por 24 horas antes de serem 
levados à máquina de ensaios. O teste de microinfiltração foi realizado em cavidades Classe V na face vestibular de 15 caninos humanos e 15 incisivos bovinos.

Obtiveram os seguintes resultados com relação à resistência de união ao cisalhamento a dentina de humanos $=6,2 \pm 2,9 \mathrm{MPa}$; e a de bovinos = 4,4ะ1,2 MPa. A resistência de união à dentina humana foi consideravelmente maior e a microinfiltração muito menor do que a dentina de bovinos. Concluíram que o uso de dentes bovinos ao invés de dentes humanos, nestes tipos de testes, não é indicado ${ }^{78}$.

ATTIN et al. ${ }^{2}$, em 1994, verificaram se o uso de pinos rosqueáveis melhora a resistência de restaurações Classe IV, utilizando pinos com e sem cobertura com resina opaca.

Foi realizado um preparo de Classe IV em 64 incisivos bovinos recémextraídos, conforme medidas apresentadas na Figura 13. A extensão vestíbulo-lingual variou devido às diferenças morfológicas dos dentes (em torno de $5 \mathrm{~mm}$ ).

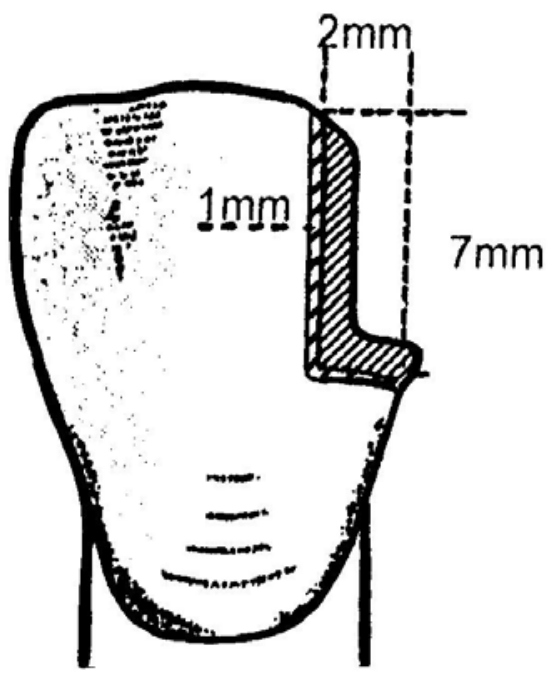

FIGURA 15 - Vista vestibular do preparo padronizado por ATTIN et al. ${ }^{2}$

As cavidades foram condicionadas com ácido fosfórico a 37,5\% por 60 segundos e os pinos colocados de acordo com as instruções a $1 \mathrm{~mm}$ da junção esmalte dentina e metade da extensão vestíbulo-lingual. Utilizaram 
dois tipos de pinos PCR pins (Brasseler) com adesivo/resina opaca (Silicoater, Kulzer) e FO pins sem cobertura.

Após condicionamento e aplicação do adesivo Heliobond (Kulzer), a resina composta foi inserida em incrementos e polimerizada por 40 segundos.

Obtiveram os seguintes grupos:

1 - AET - Condicionamento ácido

2 - AET + PCR 2 - Condicionamento ácido + pino (PCR n.2)

3 - AET + PCR4 - Condicionamento ácido + pino (PCR n.4)

4 - AET +FO4 - Condicionamento ácido + pinos (FO n.4)

Os espécimes foram armazenados em saliva artificial por 72 horas a $37^{\circ} \mathrm{C}$. Após 48 horas, 10 dentes de cada grupo foram adicionalmente submetidos ao carregamento mecânico, simulando a mastigação. Dois dentes de cada grupo, um com e outro sem carregamento mecânico, foram analisados ao MEV para a avaliação da adaptação marginal.

Os dentes foram incluídos e levados à máquina de ensaios universal a um ângulo de $45^{\circ} \mathrm{com}$ o longo eixo do dente e a força aplicada a $1,5 \mathrm{~mm}$ do ângulo incisal; o modo de falha foi avaliado macroscopicamente.

Após análise estatística, verificaram que os dentes que não receberam carregamento mecânico não apresentaram fenda marginal entre a resina composta e o esmalte. Constataram que o envelhecimento (químico e mecânico) não teve influência significante no modo de falha. Entretanto, ao MEV, a fenda marginal foi mais freqüentemente observada nos espécimes com carregamento mecânico.

Mencionaram que :

- nenhuma fratura dental foi observada e que os pinos PCR e FO promoveram um reduzido estresse na dentina, minimizando o risco à fratura; 
- no presente estudo a associação do pino PCR com o condicionamento ácido melhorou a retenção de restaurações de Classe IV comparada somente com restaurações com o condicionamento, sendo este aumento em torno de $10 \%$.

Finalizaram com a seguinte conclusão: desde que pinos retentivos cobertos com resina opaca aumentam somente um pouco a resistência à fratura de restaurações Classe IV, os seguintes procedimentos clínicos podem ser considerados.

1 - as cavidades grandes de Classe IV podem ser restauradas exclusivamente com a técnica do condicionamento ácido.

2 - se as restaurações falharem, somente o uso do pino com resina opaca deve ser levado em consideração.

REEVES et al. ${ }^{67}$, em 1995, estudaram a microinfiltração de três sistemas adesivos para analisar o substrato dos dentes bovinos comparados aos dentes humanos relacionando a microinfiltração de alguns materiais. Utilizaram os adesivos SBMP, Prisma Universal Bond 3 e AllBond $2 \mathrm{com}$ a resina APH.

Em 30 dentes humanos e 30 bovinos, foram preparadas cavidades de Classe $\mathrm{V}$ até a junção amelocementária, com bisel da margem de esmalte em $45^{\circ}$. Os dentes restaurados foram armazenados em água a $37^{\circ} \mathrm{C}$ por três dias, termociclados entre $4{ }^{\circ} \mathrm{C}$ e $58^{\circ} \mathrm{C}$ em 100 ciclos e mantidos em água destilada a $37^{\circ} \mathrm{C}$ por quatro dias. Depois foi aplicado esmalte para unhas e colocados em isótopo de $45 \mathrm{Ca}$ por duas horas. Os corpos-de-prova foram seccionados e obtidas as auto-radiografias.

Não houve diferença significante com o substrato sobre a microinfiltração na margem incisal e gengival. Enquanto que na a margem incisal nos bovinos infiltrou menos e a gengival mais do que os mesma dentes humanos. 
Concluíram que não houve diferença significante entre a microinfiltração nos substratos humanos e bovinos. $\mathrm{E}$ os resultados sugerem que dentes bovinos podem ser usados em substituição aos dentes humanos para testes in vitro de microinfiltração. 
PROPOSIÇÃO 


\section{PROPOSIÇÃO}

Com base nos resultados e opiniões transcritas na revista da literatura e as hipóteses levantadas na introdução, o presente trabalho propõe-se a avaliar a ocorrência ou não de infiltração em cavidades de Classe IV preparadas, sem e com a presença do bisel em todo o contorno do esmalte, e depois restauradas em dentes bovinos nas seguintes condições:

- trinta cavidades de Classe IV,15 com e 15 sem bisel periférico, restauradas pelo sistema adesivo - ataque ácido mais resina adesiva (Single Bond - 3M) mais resina composta (Z-250 3M).

- Submeter as restaurações a ensaios de ciclagem térmica e ciclagem mecânica (carregamento de compressão sobre a face lingual das restaurações. 


\section{MATERIAL E MÉTODOS}




\section{MATERIAL E MÉTODOS}

\subsection{Considerações iniciais}

Treinamentos prévios foram realizados para obtenção de maior uniformidade em todos os procedimentos da metodologia que será descrita.

Todos os corpos-de-prova foram preparados por um mesmo operador com a finalidade de evitar vícios ou técnicas diferentes: os corpos-de-prova foram preparados alternadamente e não a totalidade de um mesmo grupo.

\subsection{Seleção dos dentes}

Neste estudo foram utilizados 30 incisivos bovinos divididos em 2 grupos de 15 dentes cada. Selecionados os dentes com maior higidez, foram descartados os que apresentaram desgaste acentuado da borda incisal ou defeitos estruturais nas coroas dentárias.

Os dentes eram provenientes de um frigorífico da cidade de Bauru ${ }^{1}$ e imediatamente após a exodontia foram armazenados em solução fisiológica a $1 \%$ timol, preparada pelo Departamento de Bioquímica da Faculdade de Odontologia de Bauru, da Universidade de São Paulo. Estes dentes foram limpos por raspagem com curetas de Gracey $^{2}$ e lâminas de bisturi ${ }^{3}$ n. $12 \mathrm{e}$ a profilaxia feita com escova de Robson associada à pedra pomes com água. Foram armazenados na referida solução à tempetatura de $4 \pm 2{ }^{\circ} \mathrm{C}$ (refrigerador doméstico) até o momento da preparação dos corpos-de-prova.

\footnotetext{
${ }^{1}$ - Frigorífico Mondelli, Bauru - SP

2 - Cureta de Gracey 13 e 14, 11 e 12

3 - Lâmina de bisturi BD No 12 Becton Dickinson Ind. Cirúrgicas Ltda
} 


\subsection{Grupos}

Após a seleção os dentes foram divididos aleatoriamente em dois grupos.

TABELA 1 - Apresentação dos grupos experimentais em relação a número de dentes e a presença ou ausência do bisel

\begin{tabular}{c|c|c}
\hline Grupos & Número de dentes & Bisel \\
\hline 1 & 15 & Ausente \\
\hline 2 & 15 & $\begin{array}{c}\text { Em todo ângulo } \\
\text { cavossuperficial }\end{array}$ \\
\hline
\end{tabular}

\subsection{Preparo das Cavidades}

Cavidades Classe IV sem bisel e com bisel em todo o contorno do ângulo cavossuperficial foram previamente demarcadas com auxílio de um paquímetro ${ }^{1}$ e uma régua milimetrada flexível de precisão. Na face mesial por vestibular, delimitada a lápis (grafite de $0,5 \mathrm{~mm}$ de diâmetro), a futura margem da cavidade tinha as seguintes dimensões: $3 \mathrm{~mm}$ no sentido mésiodistal, e 10 mm no sentido inciso-cervical; no vestíbulo-lingual não pôde ser padronizada exata e sim aproximadamente, devido às variações anatômicas e de tamanho existentes entre os dentes bovinos. Esta medida em nível da parede gengival variou no intervalo de 5 a $6 \mathrm{~mm}$ (média $=5,5 \mathrm{~mm}$ ) - Figura 16.

Os preparos foram realizados com brocas diamantadas ${ }^{2}$ n. 2143 K.G. Sorensen, substituídas a cada cinco dentes, em uma turbina Extra Torque (Kavo-Joinville-SC), girando em alta velocidade com abundante refrigeração de água/ar.

1 - Paquímetro Stainless Hardened VIS (made in Poland)

2 - Broca diamantada KG Sorensen Ind. Com. Ltda, São Paulo 
No grupo dos dentes com bisel, após a realização da cavidade foi delimitada a extensão do bisel utilizando uma régua milimetrada flexível, a 1,0 mm da margem cavitária, para obter a largura mais uniforme possível.

O bisel foi realizado em esmalte ao longo de todo o ângulo cavossuperficial utilizando broca diamantada ${ }^{1}$ n. 3118 em alta velocidade posicionada, em ângulo de $45^{\circ} \mathrm{com}$ a margem cavitária.

\section{Grupo 1 - Cavidades Classe IV "sem bisel"}

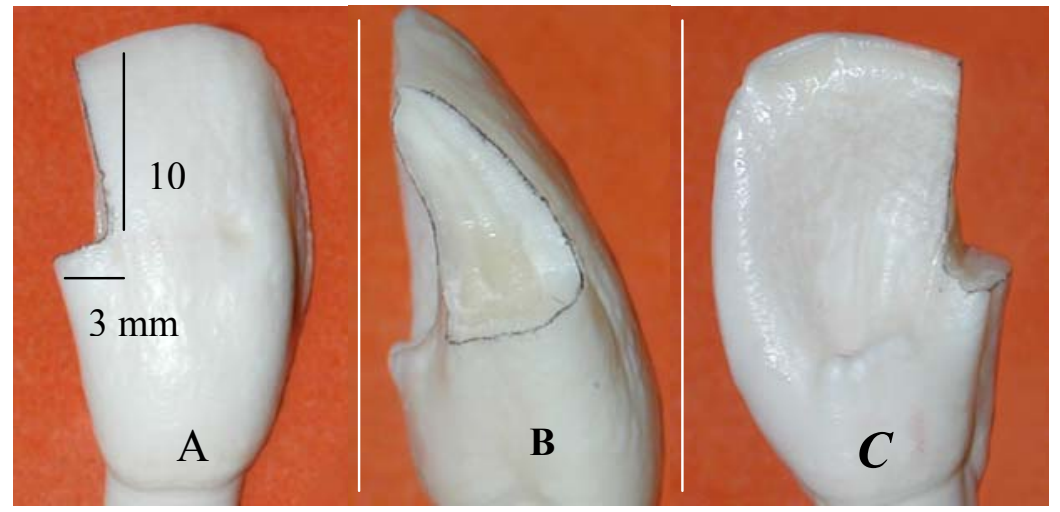

FIGURA 16 - A- Vista vestibular B- proximal C- lingual

\section{Grupo 2 - Cavidades Classe IV "com bisel”}
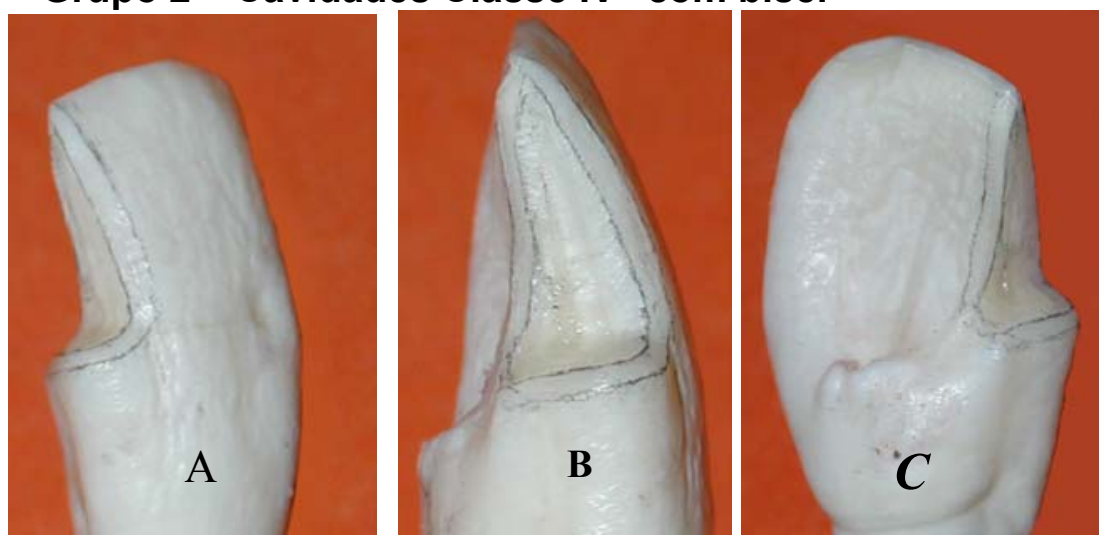

FIGURA 17 - A- Vista vestíbulo-proximal C- línguo-proximal

B- proximal

${ }^{1}$ - Broca diamantada KG Sorensen Ind. Com. Ltda, São Paulo 


\subsection{Procedimentos restauradores}

\subsubsection{Limpeza cavitária}

Em todas as cavidades utilizou-se o detergente aniônico TERGENSOL, INODON ${ }^{1}$, como agente de limpeza aplicado de forma ativa por 30 segundos. Após este período, lavava-se por cinco segundos com jato de ar lágua.

\subsubsection{Condicionamento Ácido}

As cavidades dos grupos 1 e 2 foram condicionadas com ácido fosfórico ${ }^{2}$ a $35 \%$ (3M), na forma de gel. A aplicação direta nas cavidades foi feita com a ponta aplicadora fornecida com o produto, por 15 segundos, tanto em esmalte como em dentina; as cavidades foram lavadas por 15 segundos e o excesso de umidade foi removido com guardanapo de papel absorvente, previamente cortado.

\subsubsection{Aplicação de Adesivo}

Foram aplicados duas camadas consecutivas por 15 segundos de adesivo $^{3}$ Single Bond ao esmalte e dentina, utilizando uma ponta de pincel saturada com produto. $O$ frasco foi imediatamente fechado com o cuidado de evitar a volatilização de seus componentes. Os materiais passaram por uma leve secagem com jato de ar, livre de contaminação por 30 segundos, a uma distância de $30 \mathrm{~cm}$ para eliminar o solvente do adesivo.

\subsubsection{Fotopolimerização}

Após a aplicação do adesivo a fotopolimerização foi feita com aparelho Optilux ${ }^{4}$, por dez segundos, com intensidade de luz $700 \mathrm{~mW} / \mathrm{cm} 2$, conferida com radiômetro ${ }^{5}$ Model 100.

\footnotetext{
1 - Tergensol Inodon - Ind. De Produtos Odontológicos Ltda. Porto Alegre-RS, Lote 0504

2 - Ácido Fosfórico, Scotchbond 3M Dental Products St Paul, MN 55144, USA. Lote 14081

3 - Single Bond Adhesive, 3M Dental Products St. Paul, MN 55144, USA. Lote 14081

${ }^{4}$ - Optilux = Demetron Research Corporation, Model No VCL -401 , Serial $-N^{\circ} 4823933$

5 - Radiômetro Model 100 "Curing Radiometer" P/N 10.503, Serial № 116095 Demetron Research Corporation Danbury, CT 06810-7377 U.S.A.
} 


\subsubsection{Restauração}

A resina composta selecionada pertence ao grupo de resinas híbridas, restauradoras para dentes anteriores e posteriores.

Utilizou-se o Restaurador ${ }^{1}$ Filtek Z-250 (3M) na cor C-2 (Figura 18), a qual foi inserida em incremento único com espátula ${ }^{2}$ Greenste para, em seguida, ser fotopolimerizada por $20 \mathrm{~s}$ e $700 \mathrm{~mW} / \mathrm{cm}^{2}$ (com variação de \pm 15 $\mathrm{mW} / \mathrm{cm}^{2}$ ). Antes de cada período de uso do referido aparelho, a intensidade de luz era averiguada pelo referido radiômetro.

As restaurações foram realizadas de forma a deixar mínimo excesso possível, assim como evitar que o sistema adesivo se espalhasse em demasia para fora dos limites cavitários.

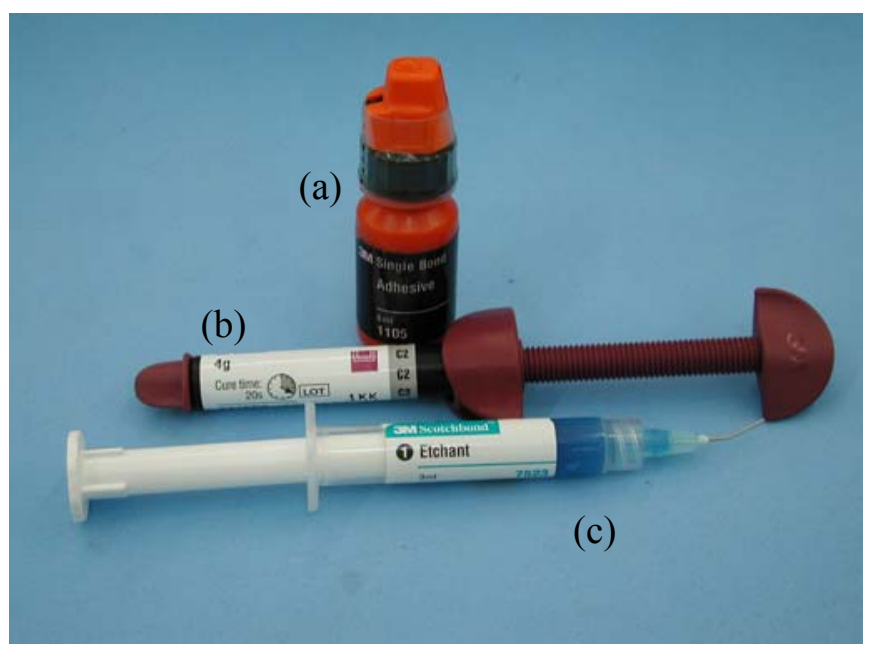

FIGURA 18 - Conjunto restaurador adesivo:

(a)- Sistema Adesisvo Single Bond

(b)- Resina Composta Filtek Z-250

(c)- Agente Condicionador (3M)

1 - Fitek Z-250, Universal Restorative C2 Shade, Lote 14081 (3M) Dental Products, USA.

2 - Espátula Greenste Incolor Safident CH.1196 GLAND, made Swiss 


\subsubsection{Acabamento Imediato}

Excessos da restauração foram removidos com lâminas de bisturi n. 15 para não permitir que $\mathrm{o}$ adesivo e/ou material restaurador permanecessem além dos limites cavitários.
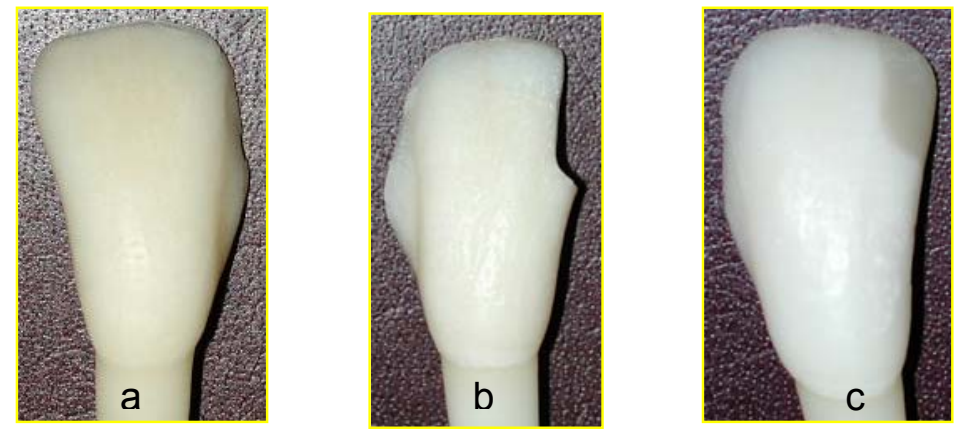

FIGURA 19 - a- Dente bovino hígido

b- Dente com cavidade Classe IV

\section{C- Dente restaurado com sistema restaurador adesivo}

\subsubsection{Armazenamento}

Concluída a restauração, os dentes foram armazenados no interior de uma estufa ${ }^{1}$, regulada à temperatura de $37^{\circ} \mathrm{C}$, permanecendo por 7 dias em recipiente com água deionizada.

\subsubsection{Acabamento, polimento, proteção dentária e reidratação}

No sétimo dia de conclusão da restauração, os dentes foram retirados da estufa para se efetuar o acabamento e polimento com disco de lixa Sof Lex marca 3M do Brasil Ltda., Sumaré - São Paulo - Brasil, de granulação média, fina e extrafina, para proteção dos dentes. A cavidade foi delimitada para que aproximadamente $1,0 \mathrm{~mm}$ ao seu redor permanecesse livre de selamento (Figura 20); foi feita a aplicação do esmalte ${ }^{2}$ de unha de secagem

1 - Estufa Fanem Ltda., São Paulo - Brasil.

2 - Esmalte de unhas, Espress Finish, Mabelline (Ultimate Wear) New York, USA. 
extra-rápida Maybelline, de ultraduração; em duas camadas, sendo a segunda aplicada depois da secagem a primeira camada. Para reidratação os dentes foram imersos em água deionizada e levados de volta à estufa com temperatura de $37^{\circ} \mathrm{C}$, por 12 horas.

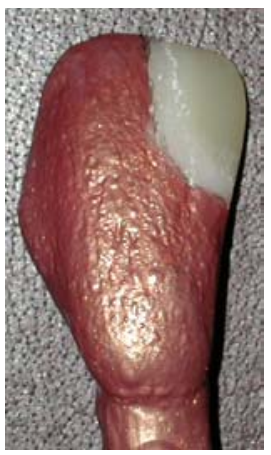

FIGURA 20 - Impermeabilização do dente com esmalte de unha cobrindo o dente, com exceção de $1 \mathrm{~mm}$ ao redor da restauração

\subsection{Procedimentos para a ciclagem térmica}

De acordo com a metodologia, os espécimes foram submetidos à termociclagem no equipamento apropriado ${ }^{1}$, previamente regulado a $5^{\circ} \mathrm{C}$ e $55^{\circ} \mathrm{C}$ de temperatura com variação de $\pm 2{ }^{\circ} \mathrm{C}$, água deionizada (Figura 21).

Foram realizados 500 ciclos, sendo os espécimes submetidos a banhos de $5{ }^{\circ} \mathrm{C}$ por 30 segundos e logo após, por banhos a $55^{\circ} \mathrm{C}$ por 30 segundos, com tempo de transição de 2 segundos.

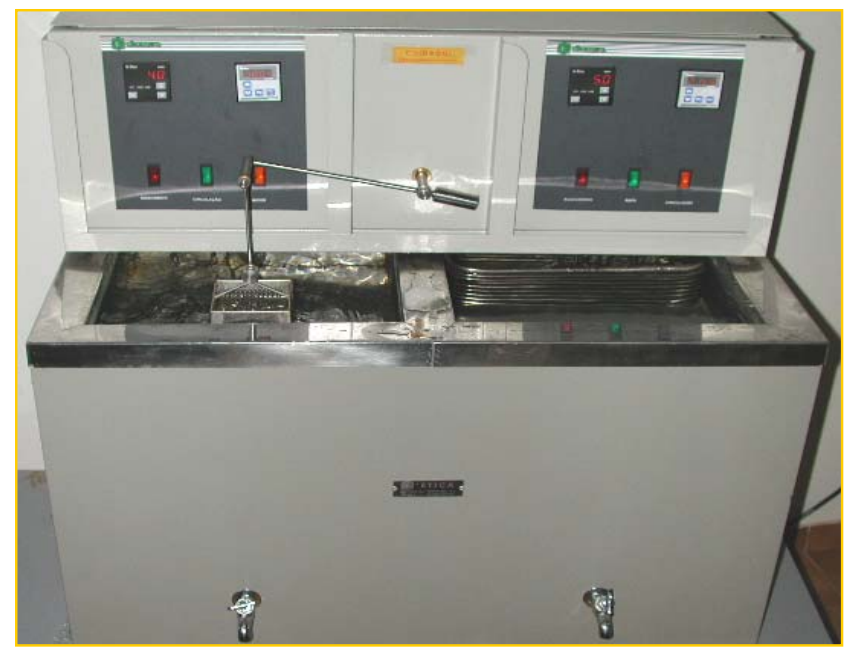

FIGURA 21 - Máquina de termociclagem, ÉTICA (pertencente ao Laboratório do Departamento de Dentística da FOB USP) onde os conjuntos dente restauração foram submetidos ao choque térmico

1 - Máquina de termociclagem Ética, São Paulo, Brasil. 


\subsection{Procedimentos prévios à ciclagem mecânica}

\subsubsection{Inclusão}

Para a ciclagem mecânica os dentes foram incluídos, por suas raízes, em tubos ${ }^{1}$ de PVC de $3 / 4$ de polegadas, cortados de forma adequada, e resina cristal" "Redelease" (Figura 22). Os anéis de PVC foram obtidos pelo seccionamento dos tubos com $6,0 \mathrm{~cm}$ de comprimento. Para que a face lingual das coroas clínicas dos incisivos ficasse exposta, o tubo de $6 \mathrm{~cm}$ foi seccionado em meia-cana (metade do comprimento do tubo de PVC) até a altura em que a coroa clínica dos incisivos ficasse exposta (Figura 22).

O tubo de 6,0 cm permaneceu sem corte em meia-cana na parte radicular e numa extensão de $2,5 \mathrm{~cm}$ de comprimento, onde a raiz foi incluída pela resina no interior desse anel. Outra extremidade do tubo com corte em meia-cana foi fechada com "cap" soldável ${ }^{3}$ ou tampa, fixada com um adesivo próprio para esse material ("Adesivo Plástico Tigre”), lacrando depois o compartimento no qual seria colocada a solução corante. Desse modo, a coroa do dente pôde ficar totalmente submersa ao corante durante a aplicação da carga de carregamento através da abertura do corte em meia-cana no tubo de PVC (Figura 23).

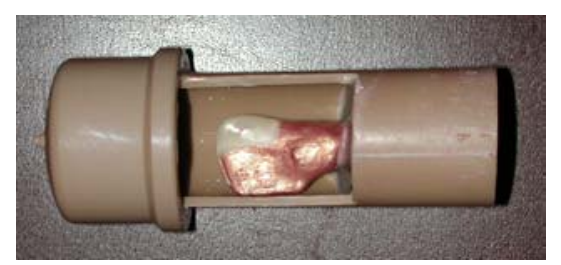

FIGURA 22 - Extremidade direita do tubo de PVC vedada com resina, que também fixava o dente por sua raiz. A extremidade esquerda foi seccionada para permitir $\mathrm{o}$ carregamento axial, através de uma ponta torneada de forma esférica com $2 \mathrm{~mm}$ de diâmetro, com tampa

\footnotetext{
1 - Tubo soldável de $25 \mathrm{~mm}$ marrom, Tigre e conexões Joinvile - SC

2 - Resina Cristal Ortofitálica, código 2021, Redelease Ltda, Lote 077-02

3 - Cap soldável de $25 \mathrm{~mm}$ (tampa), Tigre S.A. Tubos e conexões- Joinvile-SC.
} 


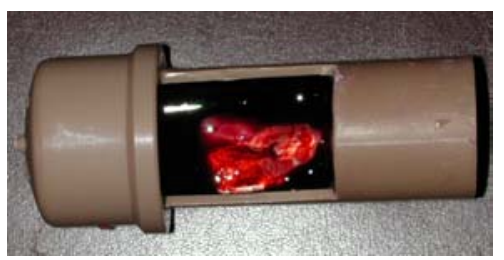

FIGURA 23 - Dente imerso na solução corante para receber a carga

Assim que a resina se tornou plástica (aproximadamente 10 minutos), o conjunto anel/resina/dente restaurado foi imediatamente submerso em água deionizada a $37^{\circ} \mathrm{C}$.

\subsection{Procedimentos para ciclagem mecânica}

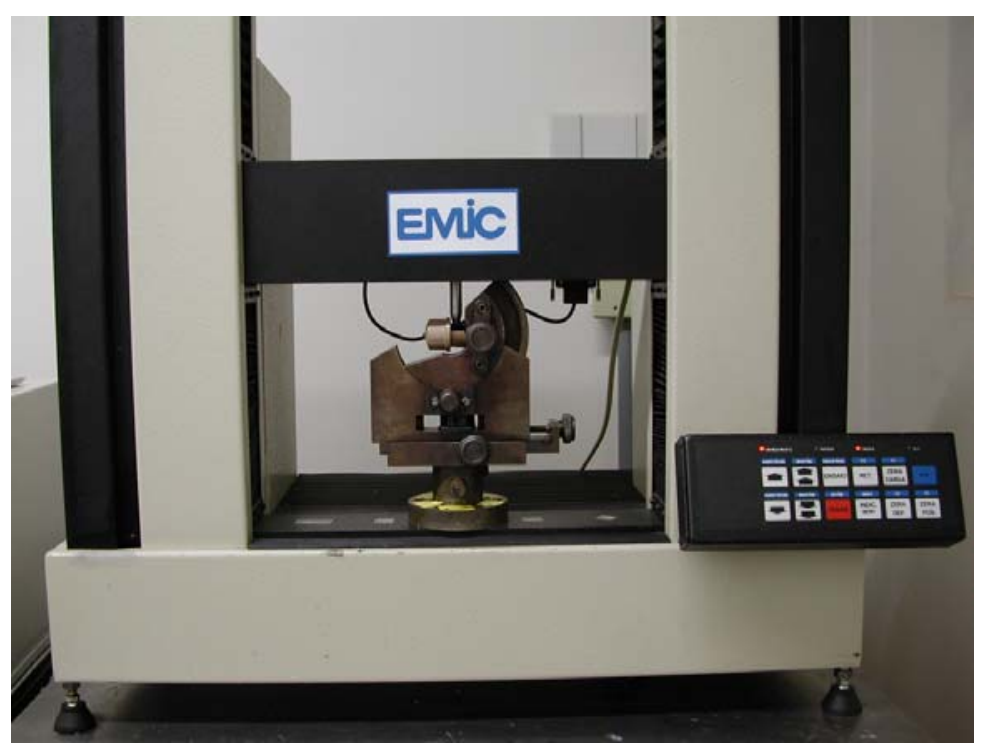

FIGURA - 24 Máquina universal de ensaio EMIC, pertencente ao Laboratório de Dentística da FOB-USP

Iniciado após 24 horas com a total polimerização da resina, estando a coroa do dente submersa na solução de corante de fuccina básica a 0,5\%, foi realizado no centro da face lingual da restauração o carregamento de compressão desenvolvido pela máquina Universal de ensaios EMIC ${ }^{1}$ (Figura 24).

\footnotetext{
${ }^{1}$ - EMIC - Equipamentos e Sistemas de Ensaios, DL-500, Paraná, Brasil
} 
Para que isso fosse possível, utilizou-se um posicionador ${ }^{1}$ de ângulos para ensaios universal com a finalidade de deixar a superfície lingual dos dentes paralela à superfície do chão, formando um ângulo de $90^{\circ} \mathrm{com}$ a ponta ativa da célula de carga (Figura 26). Foi aplicada uma carga ascendente de 1 a 10 kgf, que posteriormente regredia de forma gradual. Todo esse processo teve uma duração de 30 minutos, perfazendo um total de 100 ciclos para cada corpo-de-prova.

Durante essa fase, a fucsina básica a $0,5 \%$ era injetada com uma seringa dentro do tubo de PVC, de forma que os dentes ficassem totalmente submersos no corante.

Com o término da ciclagem, os dentes permaneceram imersos na fucsina até totalizar 24 horas de imersão (Figura 25). Em seguida, foram removidos dos tubos de PVC e lavados em água corrente por 12 horas, para eliminação do excesso do corante, e depois expostos à secagem por um período igual em condições ambiente.

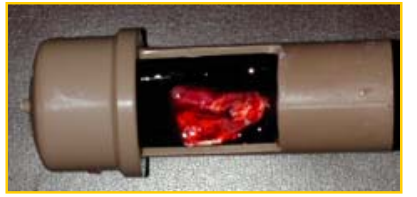

em fucsina básica, no interior do tubo de PVC

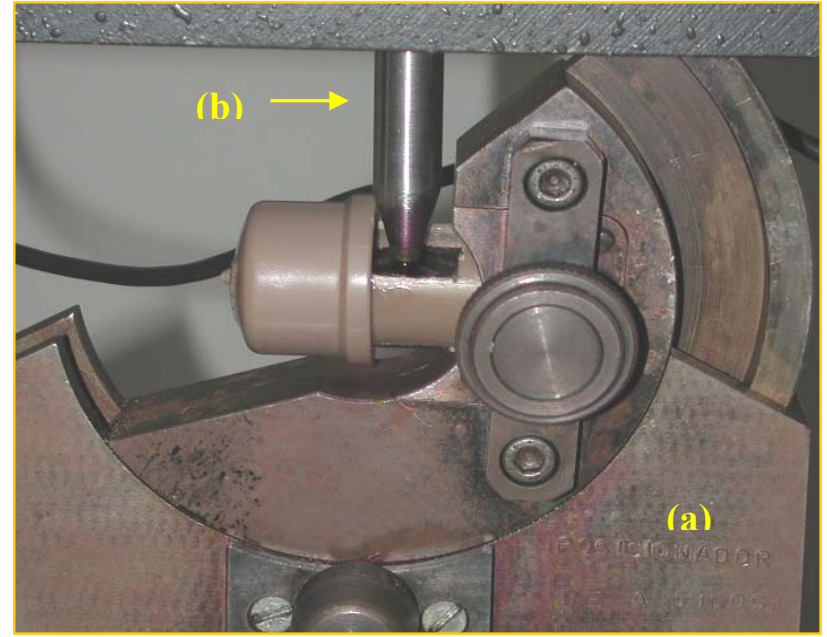

FIGURA 26 - Corpo-de-prova em posição por meio do (a)- posicionador de ângulo e (b)- ponta cônica incindindo na face palatina da restauração (no nicho preparado para não deslizar), a fim de aplicar o carregamento axial de compressão

\footnotetext{
${ }^{1}$ Posicionador de ângulo para ensaios universais, dispositivo projetado e confeccionado na escola do SENAI, José Polizotto, Marília-SP.
} 


\subsection{Técnica para o seccionamento dos dentes}

Após a secagem, cada dente foi seccionado em máquina de corte Extec $^{1}$ Labcut, com um disco de diamante girando em velocidade de 300 r.p.m. Os cortes dos espécimes foram realizados no sentido transversal ao eixo longitudinal do dente e cada um deles possuia aproximadamente 1,0 $\mathrm{mm}$ de espessura.

Para controle, cada grupo de dentes foi devidamente separado e identificado, facilitando a avaliação da microinfiltração da secção que apresentava maior grau de penetração do corante. Após o seccionamento dos dentes, as secções foram colocadas em contato com papel absorvente durante 30 min., para que a umidade fosse removida.

\subsection{Método de avaliação dos espécimes e índice de infiltração}

Foi avaliado o corte do dente que apresentou maior grau de infiltração do corante. Todas as secções selecionadas foram escaneadas junto com uma régua milimetrada de precisão, que serviu para a calibração das medidas em milímetros. As imagens obtidas das secções foram transportadas para o programa de computador Image Tools da Universidade de San Antonio - Texas (UTHSCSA), no qual se determinou a extensão linear da infiltração do corante em milímetros.

\subsection{Análise estatística}

Os resultados obtidos na medição da microinfiltração marginal dos espécimes foram submetidos ao teste de Fisher bicaudal, para comparar a proporção nos dois grupos, considerando os fatores ausência ou presença de bisel.

1 - Extec - Division of Excel Technologies INC - MODEL 1010. Labcut Low Speed Diamond Saw. 
RESULTADOS E DISCUSSÃO 


\section{RESULTADOS E DISCUSSÃO}

\subsection{Metodologia}

A infiltração marginal é a passagem de bactérias, fluídos, íons entre as paredes cavitárias e o material restaurador. Considerada como o fator de maior influência na longevidade das restaurações dentárias, pode causar desde manchamento das margens da restauração, cárie secundária, hipersensibilidade a problemas pulpares. São implicações clínicas que podem ser significativas na interface dente/material, resultando na falha de união e na formação de fendas.

A dimensão do preparo cavitário foi baseada no trabalho em dentes bovinos de ATTIN et al. ${ }^{2}$ que apresentava as medidas de $7 \mathrm{~mm}$ de altura (inciso-cervical) por $2 \mathrm{~mm}$ de largura mésio-distal e um bisel de $1 \mathrm{~mm}$ de largura em toda a margem cavitária.

Clinicamente, na região cervical, muitas vezes não se pode realizar um bisel com a dimensão de $1 \mathrm{~mm}$ devido à extensão da lesão cariosa ter eliminado grande parte da espessura do esmalte, pois quanto mais próximo da junção cemento/esmalte é menor a espessura do esmalte. Neste trabalho, pelo fato de serem dentes bovinos e hígidos, pôde-se contar com esmalte suficiente nesta região e com um bisel na medida acima citada.

O bisel chanfrado foi confeccionado com ponta diamantada n. 3118 , possibilitando maior quantidade e espessura de resina em esmalte ${ }^{15,33,57}$. Este foi realizado com $1 \mathrm{~mm}$ de largura, pois medidas acima desta não apresentam aumento significativo na retenção, segundo BAGHERI, DENEHY ${ }^{4}$. 
TAYLOR e LINCH ${ }^{81}$, afirmam que as cavidades deveriam ser as mais idênticas possíveis na tentativa de eliminar variação entre os espécimes; para tanto as dimensões das cavidades do presente trabalho foram medidas e controladas por meio de um paquímetro com 0,001 de precisão e com uma régua flexível milimetrada. Após a confecção de cada grupo experimental, os dentes foram armazenados em água deionizada a $37{ }^{\circ} \mathrm{C}$ por 7 dias, para permitir a expansão higroscópica da resina composta. A variação entre as técnicas de acabamento e polimento têm afetado a capacidade dos materiais restauradores em resistir à microinfiltração, o que está relacionado com o calor produzido durante este processo ${ }^{81}$.

A técnica de inserção de resina composta em incrementos ${ }^{52}$ é válida devido a um conjunto de fatores que favorecem as propriedades do material resinoso, bem como a adaptação marginal da restauração. Mas esta técnica não foi utilizada para produzir o máximo de estresse gerado pela contração de polimerização nos dois grupos.

Foi realizado a termociclagem, in vitro, para as restaurações e os dentes fossem submetidos à temperaturas extremas, simulando a temperatura fria e quente na cavidade bucal, podendo produzir pela expansão e contração térmica do dente e material restaurador, a abertura das margens que pode causar a infiltração marginal.

Além da ciclagem térmica, optou-se por incluir a ciclagem mecânica para simular, de forma mais aproximada, as condições existentes in vivo, de esforços mastigatórios, de acordo com várias pesquisas realizadas de infiltração marginal ${ }^{15,53,64}$. 
$\mathrm{Na}$ termociclagem foram utilizadas as temperaturas mais citadas em outros trabalhos ${ }^{6,15,24}$, as de $5^{\circ} \mathrm{C}$ e $55^{\circ} \mathrm{C}$. O tempo de imersão nos banhos foi 30 segundos $^{15,26}$, em cada recipiente, porque as resinas compostas apresentam baixa condutibilidade térmica, sendo necessário tempo maior para que a alteração térmica pudesse provocar uma alteração dimensional na interface dente/resina. O número de ciclos pode variar em média de 10.000 a uma mediana de 500 ciclos $^{15,53}$. RETIEF ${ }^{69}$ recomenda a utilização de, no mínimo, 500 ciclos para padronização dos testes, os quais foram adotados no presente estudo.

Para avaliar a infiltração nas restaurações foi utilizado o corante fucsina básica, de mais fácil aquisição e menor custo, e com a vantagem de favorecer a avaliação de todo contorno da restauração sem necessidade de uma reação química ou radiação, e também pelo seu baixo peso molecular (peso molecular $=323,83$ ).

A infiltração marginal foi avaliada por meio de penetração do corante, teste quanlitativo (linear) que mede extensão de corante penetrada na interface, sendo selecionada a secção que apresentou maior penetração em extensão de corante na interface dente/restauração. As imagens digitalizadas das secções foram avaliadas em milímetros, por meio do programa Image Tools, da Universidade de San Antonio, Texas (UTHSCSH).

Como as restaurações Classe IV de incisivos estão sujeitas à força mastigatória de 9 a $25 \mathrm{kgf}^{80}$, decidiu-se desenvolver um carregamento axial de compressão que atingia um valor máximo de $17 \mathrm{kgf}$, correspondente à média desses valores. Porém, durante os testes preliminares, a referida carga causava fratura nas restaurações, nos dentes ou deslocamento dos mesmos, motivo que levou a empregar um carregamento axial de compressão que atingia valor de $10 \mathrm{kgf}^{15}$. 


\subsection{Utilização de dentes bovinos}

Nesta pesquisa foram utilizados dentes bovinos devido à dificuldade de obtenção de dentes humanos hígidos, principalmente os anteriores, e pelo progresso do tratamento dentário conservativo. Mais ainda, devido aos critérios e deveres éticos atualmente exigidos para a utilização de dentes humanos em experimentos.

Em 1995, REEVES; et al. ${ }^{67}$ avaliaram a possibilidade do substrato de dentes bovinos ser empregado como substituto de dentes humanos em testes de infiltração marginal. Os resultados apontaram que não houve diferença estatisticamente significante entre o substrato bovino e o humano, concluindo que os dentes bovinos podem ser substitutos de dentes humanos em testes de microinfiltração.

RUEGGEBERG ${ }^{71}$ 1991, demonstra ampla divergência dos resultados com relação ao tempo ideal de armazenagem anterior aos testes de adesão e este demonstra não afetar os resultados dos testes de 45 adesivos. RETIEF ${ }^{69}$ também afirmou não haver diferença na resistência adesiva entre dentes com tempo de armazenagem de dois dias e seis meses. Assim, neste trabalho foram utilizados dentes com, no máximo, seis meses após a extração.

Para conservar as características histológicas dos dentes, sem prejudicar o processo adesivo e prevenir o risco de contaminação, houve a preocupação no armazenamento dos dentes extraídos, o que foi feito em solução salina com $1 \%$ de timol. Embora a resistência adesiva pareça não ser afetada pelo meio de armazenagem ${ }^{71}$, DeWALD ${ }^{30}$, analisando trabalhos com diversas soluções para controlar a infecção e contaminação, relata que o timol produz resultados de microinfiltração semelhantes aos dos dentes recém-extraídos. 
Devido às dificuldades de pesquisa com dentes humanos e à existência de respaldo científico ${ }^{67}$ para utilização de dentes bovinos, decidiu-se utilizálos para esta pesquisa de infiltração marginal. 


\subsection{Resultados}

A tabela 2 mostra os valores lineares médios da infiltração marginal e as respectivas médias para cada grupo experimental.

O preparo cavitário com bisel não apresentou infiltração marginal, ao contrário do preparo cavitário sem bisel (Figura 27). Houve diferença estatisticamente significante entre os dois grupos, segundo teste de Fisher bicaudal, para os dados $p<0,0001$, o que é estatisticamente significante pois $p<0,05$.

Submetidos à análise estatística, os resultados mostraram diferenças significantes entre os grupos 1 e $2, p<0,0001$ o grupo 1 , em que não se determinou a variável bisel, apresentou os maiores índices de infiltração marginal com média de 1,02 $\mathrm{mm}$. No grupo 2 a variável bisel foi realizada ao longo do ângulo cavossuperficial, observando-se valores e resultados estatísticos com significado clínico importante, uma vez que nesse grupo não houve infiltração marginal (Tabela 2).

Compreende-se que 0 biselamento de todo 0 ângulo cavossuperficial resultou numa significativa redução da infiltração marginal quando comparado com as margens não biseladas ${ }^{41,65,66}$.

O bisel produz um efeito real na redução da infiltração marginal está diretamente relacionada à forma com que os prismas de esmalte são

$\operatorname{expostos}^{50,59}$, algumas explicações de que a orientação dos prismas, expostos pelo bisel, influencia na profundidade do ataque ácido e na redução da infiltração marginal.

Dependendo da orientação dos cristais no esmalte humano e sua reatividade ao ácido foram estudadas por $\mathrm{SHARPE}^{73}$, concluindo que quando o ataque ácido ocorre de forma paralela à direção da linha 
TABELA 2 - Valores médios, desvio padrão e mediana de penetração linear do corante, medidos em milímetros

\begin{tabular}{|c|c|c|}
\hline & COM BISEL & SEM BISEL \\
\hline Espécime & Linear (mm) & Linear (mm) \\
\hline 1 & 0,0 & 0,98 \\
\hline 2 & 0,0 & 0,92 \\
\hline 3 & 0,0 & 0,93 \\
\hline 4 & 0,0 & 2,65 \\
\hline 5 & 0,0 & 1,88 \\
\hline 6 & 0,0 & 1,15 \\
\hline 7 & 0,0 & 0,0 \\
\hline 8 & 0,0 & 0,0 \\
\hline 9 & 0,0 & 0,93 \\
\hline 10 & 0,0 & 0,92 \\
\hline 11 & 0,0 & 1,97 \\
\hline 12 & 0,0 & 2,23 \\
\hline 13 & 0,0 & 0,82 \\
\hline 14 & 0,0 & 0,0 \\
\hline 15 & 0,0 & 0,0 \\
\hline Média & 0,0 & 1,02 \\
\hline D.P. & 0,0 & 0,85 \\
\hline Mediana & 0,0 & 0,93 \\
\hline
\end{tabular}


TABELA 3 - Valores de penetração do corante medidos em porcentagem

\begin{tabular}{c|cc|cc|c}
\hline & \multicolumn{3}{|c|}{ INFILTRAÇÃO } & \\
& \multicolumn{2}{|c|}{ SIM } & \multicolumn{2}{c}{ NÃO } & \\
\hline GRUPO & n. & $\%$ & n. & $\%$ & \multicolumn{2}{c}{ TOTAL } \\
& & & & & n. $\%$ \\
\hline COM BISEL & 0 & $0,0 \%$ & 15 & $100,0 \%$ & $15 \quad 100,0 \%$ \\
\hline SEM BISEL & 11 & $73,3 \%$ & 4 & $26,7 \%$ & $15 \quad 100,0 \%$ \\
\hline
\end{tabular}

n. = Número de dentes

Fisher $p<0,0001$

$\%=$ Porcentagem
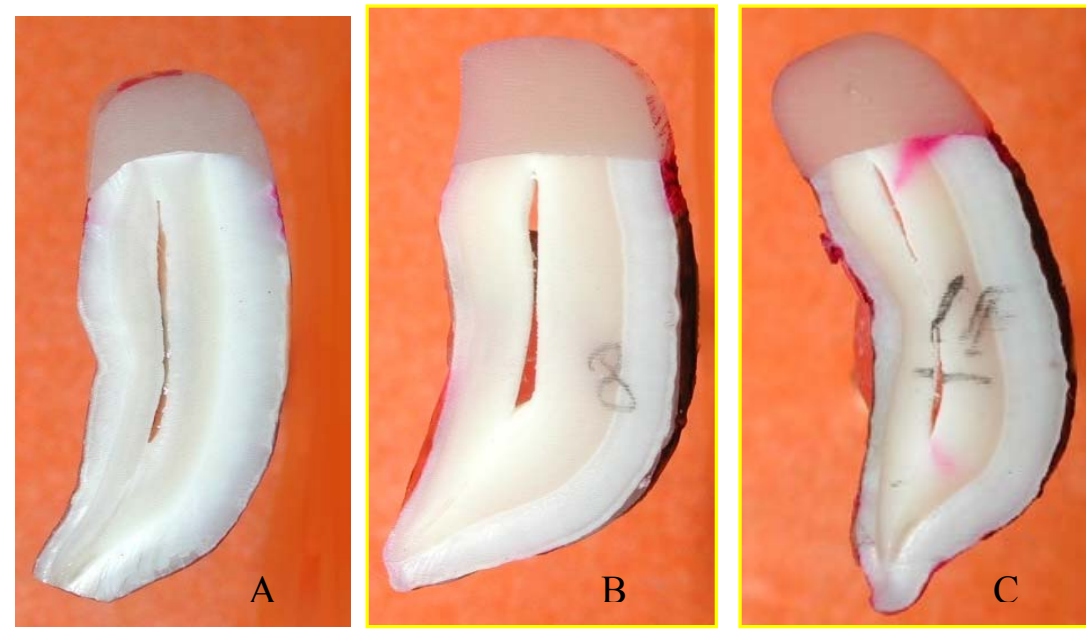

FIGURA 27 - Amostras das secções obtidas:

A - com bisel ( ausência de infiltração, 100\%); B - sem bisel ( ausência de infiltração, 26,7\%);

C - sem bisel (presença de infiltração, 73,3\%) 
prismática, é produzida uma estrutura mais reativa. Se o condicionamento ácido ocorre de forma perpendicular à direção da linha prismática, é formada uma estrutura fibrosa e menos reativa. O biselamento do esmalte permite que os prismas sejam orientados de maneira mais favorável ao ataque ácido e a cabeça do prisma seja disposta de forma paralela à direção da linha prismática.

De acordo com BUONOCORE \& MATSUI \& GWINNETT ${ }^{12}$, e GWNNET \& MATSUI ${ }^{43}$, a união da resina com o esmalte, com seus prismas cortados longitudinalmente, não é tão forte como as superfícies de esmalte se unem às resinas com os prismas cortados transversalmente.

A orientação dos prismas de esmalte tem uma grande influência na resistência de união entre as resinas compostas e o esmalte ${ }^{12,49}$. Nas margens de esmalte, a orientação dos prismas não deve ser paralela à interface resina-esmalte, porque assim micro-rachaduras, fendas e/ou fraturas provenientes da força de contração podem ocorrer.

Um aspecto clínico comum que evidencia micro-rachaduras e fendas é uma "linha branca" que se forma ao redor das restaurações. Caracteriza-se como uma degradação marginal que acontece na interface de união resinaesmalte. Para evitar a formação dessa "linha branca", a determinação do bisel das margens cavitárias torna-se imperativa ${ }^{15}$.

Segundo DAVIDSON ${ }^{28}$ (1986), as paredes aderidas são áreas de restrição de contração e as paredes livres são áreas que permitem o escoamento do material, relaxando as tensões de contração. De acordo com VERSLUIS et al. ${ }^{82}$ (1998), as resinas compostas contraem-se em direção às paredes as quais estão aderidas. Portanto, quanto menor for a área de adesão - como numa cavidade Classe IV, possibilitando ao material o relaxamento das tensões geradas na contração de polimerização devido à diminuição das superfícies aderidas TAYLOR ${ }^{81}$, menor será a tendência dessa resina se contrair em direções antagônicas, gerando menos tensões nas respectivas interfaces adesivas, as quais são minimizadas pela maior quantidade de áreas livres para escoamento. Pode ser inferido que os resultados obtidos com valores médios de penetração do corante no grupo com ausência do bisel (média $=4,20 \mathrm{~mm}$ ), no grupo com presença do bisel 
(média $=0,26)$, com menor magnitude ao verificado por CAMPOS $^{15}$, em Classe III foi em função de um fator C mais favorável à proporção de superfícies aderidas em relação às não aderidas como ocorreu nas restaurações de Classe III avaliadas por esse autor.

Há de se considerar ainda a interação do sistema restaurador adesivo com a configuração cavitária que também contribui para melhor vedamento marginal, uma vez que a força de resistência adesiva do material restaurador é aumentada no grupo 2 com a presença do bisel, mantendo-se possivelmente intacta a união entre a estrutura dentária e o material restaurador.

É também muito comum, na ausência do bisel, um aspecto de "meialua" presente nas interfaces das restaurações de Classe III e IV, normalmente relacionadas com infiltração marginal ${ }^{15}$.

Considerando que a determinação do bisel promove um desgaste da estrutura dentária e os benefícios proporcionados pelo mesmo são mais importantes que uma pequena conservação dessa estrutura, a determinação do bisel deve ser considerado um procedimento importante nas restaurações adesivas. Comprovou-se uma vez mais aquilo que BUONOCORE ${ }^{11}$ afirmara no seu livro-texto, em 1975, de que o "bisel é parte integrante do condicionamento ácido em esmalte". Ocorre união entre as resinas compostas, o esmalte e a dentina, por meio dos sistemas adesivos, com a vantagem da execução do bisel não se restringir apenas à estética e à retenção, mas à redução da infiltração marginal. 
CONCLUSÕES 


\section{CONCLUSÕES}

De acordo com a metodologia proposta, nas condições em que foi desenvolvido o experimento e pela análise estatística dos resultados obtidos, pode-se concluir que:

- O biselamento influenciou os valores de infiltração marginal;

- A presença de bisel em cavidades de Classe IV, restaurado com sistema adesivo, minimizou a infiltração marginal, quando apresentou notadamente maior diferença que sem bisel. 
REFERÊNCIAS BIBLIOGRÁFICAS 


\section{REFERÊNCIAS BIBLIOGRÁFICAS}

1. ANUSAVICE, K. J. Materiais dentários. 10 . ed. Rio de Janeiro, Guanabara Koogan, 1998.

2. ATTIN, T. et al. Fracture toughness of pin-retained class 4 restaurations. Oper. Dent., v.19, n.3, p.110-5, May/June 1994.

3. BAGHERI, J.; DENEHY, G.E. Effect of enamel bevel and restorations lengths on class IV acid-etch composite resin restoration. J. Amer. Dent. Ass. v.107, n.6, p.951-3, Dec. 1983.

4. BAGHERI, J.; DENEHY, G.E. Effect of restoration thickness at the cavosurface bevel on the classe IV acid-etched retained composite resin restoration. J. prosth. Dent. , v.54, n.2, p.175-7, Aug. 1985.

5. BARATIERI, L. N. et al. Odontologia restauradora: fundamentos e possibilidades. São Paulo, Santos, 2001.

6. BARNES, D. M. et al. Microleakage of class 5 composite resin restorations: a comparison between in vivo and in vitro. Oper. Dent., v.18, p.237-45, 1993.

7. BLACK, G.V. A work on operative dentistry: the technical procedures in filling teeth. Chicago, Medical - Dental, 1908, v.2, p.191-9.

8. BOYD, M.A.; RICHARDSON, A.S.; Frequency of amalgam replacement in general dental practice.J Canad Dent Assoc, 10 (10): 763-66, 1985. 
9. BRYANT, R.W; MARZBANI, N; HODGE KLV. Occlusal margin defects. around different types of composite resin restorations in posterior teeth. Oper Dent, v.17, p.215-21, 1992.

10. BUONOCORE, M. G.; A simple method of increasing the adhesion of acrylic filling materials to enamel surfaces. J. Dent. Res., v.34, p.849-53, Dec. 1955.

11. BUONOCORE, M. G.; DAVILA, The use of adhesives in dentistry. Springfield, Thomas, 1975. 450p.

12. BUONOCORE, M. G.; MATSUI, A..; GWINNETT; A. J.; Penetration of resin dental materials into enamel surfaces with reference to bonding. Archs Oral Biol., v.13, p.61-70, 1968.

13. BUSATO, A. L. S. et al. Dentística: restaurações em dentes anteriores São Paulo, Artes Médicas, 1997.

14. BUSATO, A. L. S.; HERNANDES, P.A .G.; MACEDO, R. P. Dentística: restaurações estéticas. São Paulo, Artes Médicas, 2002.

15. CAMPOS, B. B. Efeito do bisel na infiltração marginal de restaurações de classe III, de resina composta. Bauru, 2002. 103p. Dissertação (Mestrado). Faculdade de Odontologia de Bauru, Universidade de São Paulo.

16. CARDOSO, P.E.C.; BRAGA, R.R.; CARRILHO, M.R.O. Evaluation of microtensile, shear and tensile test determining the bond strength of three adhesive systems. Dent. Mater., v.14, n.6, p.394-98, Nov.1998. 
17. CARVALHO, R.M. Adesivos dentinários fundamentos para aplicação clínica. Rev. Dent. Restauradora, v.1, n.2, p.65-6, abr./jun. 1998.

18. CARVALHO, R. M. et al. Effects of prism orientation on tensile strength of enamel. J. Adh. Dent., v.2, n.4, p.251-57, 2000.

19. CHAIN, D. C. N.; COOLEY, R. L. Direct anterior restorations In: SCHAWARTZ, R. S.; SUMMITT, J. B.; ROBBINS, J. W.

Fundamentals of operative dentistry: a contemporary approach. Chicago, Quintessence, 1996. Cap.7, p.187-205.

20. CHAN, M. C.; RODRIGUES, C. C. Como utilizar os adesivos com máxima eficiência. In: LIMBERTE, M. S. ; MONTENEGRO, J. R. Estética do sorriso: arte e ciência. São Paulo, Santos, 2002. Cap.13, p.167-82.

21. Charbeneau, G. T. et al. Principles and practice of operative dentistry. London. Lea \& Febiger, 1975.

22. CONCEIÇÃO, E. N. et al. Dentística saúde e estética: restaurações de resina composta direta em dentes anteriores. Porto Alegre, Artes Médicas, 2000.

23. CORREA, A. A. Los principios mecanicos y las formas de resistência y retencion. In PARULA, N. et al. Tecnica de operatoria dental. 3 ed. Buenos Aires. ODA. 1954. P. 409-40. 
24. COSTAÑEDA, J. C. Avaliação da microinfiltração em restaurações mistas de Classe V. Influência da contração de polimerização da resina composta, associado ao desenho cavitário, ao tratamento da superfície do cimento de ionômero de vidro e à ciclagem térmica. Bauru, 1991. 201 p. Dissertação (Mestrado) Faculdade de Odontologia de Bauru, Universidade de São Paulo.

25. CRISPIN, B. J. Contemporary esthetic dentistry: practic fundamentals. Tokyo, Quintessence, 1994.

26. DARBYSHIRE, P. A.; MESSER, L. B.; DOUGLAS, W.H. Microleakage in class II composite restorations bonded to dentin using thermal and load cycling. J. dent. Res., v.67, n.3, p.585-87, 1988.

27. DARVENIZA, M. Cavity design for class IV composite resin restorations a systematic approach. Aust. dent. J., v.32, n.4, p.270-5, Aug. 1987.

28. DAVIDSON, C. L. Resisting the curing contraction with adhesive composites. J. prosth. Dent., v.55, n.4, p.446-7, Apr. 1986.

29. DENEHY, G.E.; DOERING, J.V.; TORNEY, D.L. Occlusion for successful class IV acid-etch restorations. J. prosth. Dent., v.44, n.3, p.274-8, Sept. 1980.

30. DeWALD, J. P. The use of extracted teeth for in vitro bonding studies: a review of infection control considerations. Dent. Mater. v.13, n.2, p.74-81, Mar. 1997.

31. DOGON, I.L.; NATHANSON, D.; VAN LEEWEN, M.J. A long term clinical evaluation of class IV acid-etched composite restorations. Compend. of Continuing Educ. Dent., v.1, n.6, p.385-90, Nov./Dec. 1980. 
32. ELDERTON, RJ. Research on cavity design for amalgam

restorations.In: Proceedings of the international symposium on amalgan and tooth-coloured restorative materials. Nijmegen, The Netherlands, University of Nijmegen. p.241, 1975.

33. ELIASSON, S. T.; HILL, G. L. Cavosurface design and marginal leakage of composite resin restorations. Oper. Dent., v.2, p.55-8, 1977.

34. ERIKSEN, H. M.; BUONOCORE, M. G. Marginal leakage with different composite restorative materials in vitro. J. Oral Rehab., v. 3, p. 31522,1976 .

35. FRAGA, R.C. Dentística: bases biológicas e aspectos clínicos, Rio de Janeiro, Medsi, 1997. P. 194-205.

36. FRAGA, R. C.; FRAGA, L. R. L. Dentística: bases biológicas e aspectos clínicos. 2 ed. Rio de Janeiro, Medsi, 2001.

37. GALAN, Jr.; NAMEN, F. M., Dentística restauradora: o essencial para o clínico. Ed. Santos, São Paulo, 1998.

38. GARONE FILHO, W.; GARONE NETO, N. Estudos da superfície interna do esmalte através do microscópio eletrônico de varredura. Rev. Ass. Paul. Cirurg. Dent., v.30, p.336-71, 1976.

39. GOING, R.E. Microleakage around dental restaurations: a summarizing review. J. Amer. Dent. Ass., v.84, n.6, p.1349-1357, June 1972. 
40. GRIEVE, A. R.; SAUNDERS, W. P.; ALANI, A.H. The effects of dentine bondingn agents on marginal leakage of composite restorations-long-term studies. J. Oral Rehab., v.20, p.11-18, 1993.

41. GRIEVE, AR. The occurrence of secondary caries-like lesions in vitro. Brit Dent J, 134: p.530-36, June 1973.

42. GROSS, L; GOLDBERG, AF. Reduction of carious lesions at the margins of restorations. Caries Res, V.8, n.2, p.1034-35, 1974.

43. GWINNET, A. J.; MATSUI, A. A study of enamel adhesives. The physical relationship between enamel and adhesive. Archs Oral Biol., v.12, p.1615-20, 1967.

44. HALL, L. H. S.; COCHRAN, M. A.; SWARTZ, M. L. Class 5 composite resdin restorations: margin configurations and the distance from the CEJ. Oper. Dent., v.18, p. 246-50, 1993.

45. HARDISON, J.D. Preparation and restoration of anterior teeth with composite resin: a survey of dental schools. Oper. Dent., v.12, n.3, p. 95-9, July 1987.

46. HINDING, J.H. The acid-etch restoration: a treatment for fracture anterior teeth. J. Dent. Child., v.40, n.1, p.21-4, Jan./Feb. 1973.

47. HOELSCHER, D. C. et al. Effect of light source position and bevel placement on facial margin adaptation of resin-based composite restorations. Amer.J. Dent., v.13, n.4, p.171-75, Aug. 2000. 
48. HOWARD, W. Atlas of operative dentistry. 2 ed. Saint Louis, Mosby, 1968.

49. IKEDA, T. et al. Relation of enamel prism orientation to microtensile bond strength. Amer. J. Dent., v.15, n.2, p.109-113, 2002.

50. KANCA, J. Use of $45^{\circ}$ cavosurface margin reduces occlusal surface dye penetration. J. dent. Res., v.79, p.616, 2000. Special issue. / Abstract n.3777.

51. KIDD, E. A. M.; Microleakage: a review. J. Dent., v.4, n.5, p.199-206, Sept.1976.

52- LUTZ, F.; KREJCI, I; OLBENBURG, T.R. Elimination of polymerization estresses at the margins of posterior composite resin restorations: a new restorative technique. Oper. Dent., v.17, n.12, p.777-84, Dec. 1986.

53. MONDELLI, A . L. Avaliação da infiltração marginal em cavidades de classe II restauradas com resina composta associada a outros materiais de inserção direta. Bauru, 1999. 226p. Tese (Mestrado) - Faculdade de Odontologia de Bauru, Universidade de São Paulo.

54. MONDELLI, J. et al. Dentística: procedimentos pré - clínicos, São Paulo,. Premier, 1998.

55. MONDELLI, J. et al. Dentística: Procedimentos Pré - clínicos, São Paulo, Santos, 2002. 
56. MONDELLI, J. et al. Dentística operatória. 4 ed, São Paulo, Sarvier, 1979.

57. MONDELLI, J. et al. Dentística restauradora: tratamentos clínicos integrados, São Paulo, Pancast, 1990.

58. MONDELLI, J. et al. Restaurações estéticas, São Paulo, Sarvier, 1984.

59. MUNECHIKA, T. et al. A comparison of the tensile strengths os composite resins to longitudinal and transverse sections of enamel prisms in human teeth. J. dent. Res., v. 63, n. 8, p.1079-1082, Aug. 1984.

60. NAKAMICHI, I.; IWAKU, M.; FUSAYAMA, T. Bovine teeth as possible substitutes in the adhesive test . J. dent. Res., v.62, n.10, p. 107681. Oct. 1983.

61. NEUMEYER, S. et al. PCR pin-anchored anterior fracture restaurations. Gen. Dent., v.40, n.3, p.200-2, June 1992.

62. OILO, G; JORGENSEN, K. D. Effect of bevelling on the occurrence of fractures in the enamel surrounding composite resin fillings. J. Oral. Rehab., v.4, p.305-9, 1977.

63. PARULA, N. Técnica de operatoria dental. 5. ed. Bueno Aires, Mundi, 1972. Cap. 18, p.223-430. 
64. PEREIRA, M. A . Avaliação da infiltração marginal em cavidades de classe II restauradas com dois tipos de resinas compostas. efeito do carregamento oclusal e de técnicas de inserção.

Bauru, 1999. 130p.Tese (Mestrado) - Faculdade de Odontologia de Bauru, Universidade de São Paulo.

65. PORTE, A. et al. Cavity desings for composite resins. Oper. Dent., v.9, p.50-6, 1984.

66. QVIST, V. Marginal adaptation of composite restorations performed in vivo with different acid-etch restorative procedures. Scand J Dent Res, v.93, p. 68-75, 1985.

67. REEVES , G. W. et al. Microleakage of new dentin bonding systems using human and bovine teeth. Oper. Dent., v.20, n.6, p.230-5, Nov./Dec. 1995.

68. RETIEF, D.H.. et al. Extracted human versus bovine teeth in laboratory studies. Amer. J. Dent., v.3, n.6, p.253-8, Dec. 1990.

69. RETIEF, D.H. Standardizing laboratory adhesion tests. Amer. J. Dent., v.4, n.5, p.231-6, Oct. 1991.

70. ROBERTS, M.W.; MOFFA, J.P. Restoration of fractured incisal angles with na ultraviolet activeted sealant and a composite resin - a case. report J. Dent. Child., v.39, n.5, p. 364-5, Sep./Oct. 1972.

71. RUEGGEBERG, F.A. Substrate for adhesion testing to tooth structure - review of the literature. Dent. Mater., v.7, n.1, p.210, Jan. 1991. 
72. SAUNDERS, W.P. The shear impact retentive strengths of four dentine bonding agents to human and bovine dentine. J. Dent., v.16, n.5, p.233-8, Oct. 1988.

73. SHARPE, A . N. Influence of the crystal orientation in human enamel on its reactivity to acid as shown by high resolution microradiography. Archs Oral Bio., v.12, p.583-91, 1967.

74. SMALES, R. J. Effects of enamel - bonding, type of restoration, patient age and operator in the longevity of na anterior composite resin. Amer. J. Dent., v.4, n.3, p.130-3, June 1991.

75. SMITH, R. L.; HOOD, J. A. A .; STOKES, A . N. Influence of cavosurface configuration and compostite resin type on impact fracture resistance of class IV restorations. New Zealand Dental Journal, v.86, p.58-61, 1990.

76. SILVA e SOUZA JÚNIOR, M. H.; CARVALHO, R.M.; MONDELLI, R. F.L.Odontologia estética: Fundamentos e aplicações clínicas. São Paulo,Santos, 2000.

77. SOCKWELL, C. L. Clinical evaluation of anterior restorative materials. Dent. Clin. N. Amer., v.20, n.2, p.403-22, Apr. 1976.

78. SOUZA, J. B. Resistência ao deslocamento de restaurações de classe IV com e sem pinos rosqueáveis em dentina, sob carregamento de compressão. Bauru, 2000. 149p. Tese (Doutorado) - Faculdade de Odontologia de Bauru, Universidade de São Paulo. 
79. STARKEY, P.E.; AVERY, D. R. The acid etched restoration for fractured anterior teeth. J. Indiana Dent. Ass., v.52, n.4, p.157-60, Apr. 1973.

80. TAN, D. E.; TJAN, A. H. L. Margin designs and fracture resistance of incisal resin composite restorations. Amer. J. Dent., v.5, n.1, p.1518, Feb. 1992.

81. TAYLOR, M. J.; LYNCH, E. Marginal adaptation. J. Dent., v.21, n.5, p.265-73, Oct./Nov. 1993.

82. VERSLUIS, A.; TANTBRIROJN, D.; DOUGLAS, W. H. Do dental composites always shrink toward the light? J. dent. Res., v.77, n.6, p.1435-45,June 1998.

83. WALTON, R.E.; Microleakage of restorative materials. Oper. Dent., v.12, n.4, p.138-9, Autumn, 1987.

84. YATES, J. L.; HEMBREE, J.H. Fracture resistance of class IV composite restorations. Arkansas dent. J., v.48, n.2, p.10-4, June 1977.

85. ZIVKOVIC, S.; Quality assessment of marginal sealing using 7 dentin adhesive systems. Quint. Int., v.31, n.6, p.423-29, June 2000. 
ABSTRACT 


\begin{abstract}
The purpose of this study was to evaluate the effect of bevel in the microleakage in restorations of composite resin, in cavities Class IV with bevel and without bevel around all the cavosurface margins, submitted to a thermal and mechanical cycled.

The same dimensions was prepared, varying in the bevel presence or absence, thirty cavites of Class IV bovine teeth. Thereby, in group 1 the bevel was not done and in group 2 the bevel of $1 \mathrm{~mm}$ length was done around all the cavosurface margins. The cavities was restored with Single Bond / Z-250 (3 M). After restored, all restorations were finished with a scalpel. Afterwards, they were stored in deionize water at $37^{\circ} \mathrm{C}$ for seven days followed by the polishing procedures.

All the groups were submitted to thermocycling 500 times between $5{ }^{\circ} \mathrm{C}$ and $55^{\circ} \mathrm{C}$, in a 30 seconds dwell time. For the mechanical cycled test, it was used the EMIC machine which was programmed to execute an axial load of $10 \mathrm{kgf}$, during 30 seconds in the lingual surface of the restorations. During the mechanical cycled test, the crown of the teeth remained submerse in a 0,5\% basic fuchsin, and continued submerse until 24 hours had been completed. After that, the teeth were left 12 hours in the running water, followed by the section.
\end{abstract}

Each tooth was parted in transversal sections with approximately 1,0 $\mathrm{mm}$ and the section with the higher amount of dye penetration was selected. It was used a program (Image Tool) to make possible an analysis of the images, to determined the dye penetration in milimeters.

Through the results it is clearly that, there was a significant statistic difference $(p<0,05)$ between group 1 (absence of bevel) and group 2 (presence of bevel), which had $1,02 \mathrm{~mm}$ and $0,0 \mathrm{~mm}$ averages of dye penetration respectively.

It was concluded that the procedure of bevel execution reduce expressively the microleakage around the margins of the restorations. 